In-kind conservation payments crowd in environmental values and increase support for government intervention: A randomized trial in Bolivia

Grillos, Tara; Bottazzi, Patrick; Crespo, David; Asquith, Nigel; Jones, J.P.G.

\title{
Ecological Economics
}

DOI:

10.1016/j.ecolecon.2019.106404

Published: 01/12/2019

Peer reviewed version

Cyswllt i'r cyhoeddiad / Link to publication

Dyfyniad o'r fersiwn a gyhoeddwyd / Citation for published version (APA):

Grillos, T., Bottazzi, P., Crespo, D., Asquith, N., \& Jones, J. P. G. (2019). In-kind conservation payments crowd in environmental values and increase support for government intervention: $A$ randomized trial in Bolivia. Ecological Economics, 166, [106404].

https://doi.org/10.1016/j.ecolecon.2019.106404

Hawliau Cyffredinol / General rights

Copyright and moral rights for the publications made accessible in the public portal are retained by the authors and/or other copyright owners and it is a condition of accessing publications that users recognise and abide by the legal requirements associated with these rights.

- Users may download and print one copy of any publication from the public portal for the purpose of private study or research.

- You may not further distribute the material or use it for any profit-making activity or commercial gain

- You may freely distribute the URL identifying the publication in the public portal ?

Take down policy

If you believe that this document breaches copyright please contact us providing details, and we will remove access to the work immediately and investigate your claim. 


\title{
In-kind conservation payments crowd in environmental values and increase support for government intervention: \\ A randomized trial in Bolivia
}

\author{
Tara Grillos* \\ Department of Political Science, Purdue University, 100 N. University Street, West Lafayette, \\ IN, United States; tgrillos@purdue.edu \\ Patrick Bottazzi ${ }^{1}$ \\ School of Environment, Natural Resources and Geography, Thoday Building, Deniol Road, \\ Bangor, LL57 2UW \\ David Crespo \\ Universidad Mayor de San Simón \\ Calle Nataniel Aguirre $\mathrm{N}^{\circ} 0466$, Cochabamba, Bolivia; dcrespoforestal@gmail.com \\ Nigel Asquith ${ }^{2}$ \\ Harvard Forest, 324 North Main Street, Petersham, MA 01366 \\ Sustainability Science Program, Kennedy School of Government, Harvard University, 79 JFK \\ Street Cambridge, MA 02138 \\ Julia P.G. Jones ${ }^{3}$ \\ School of Environment, Natural Resources and Geography, Thoday Building, Deniol Road, \\ Bangor, LL57 2UW
}

17

Acknowledgements: We wish to thank the staff at Fundación Natura Bolivia, particularly Maria Teresa

Vargas, Tito Vidaurre and Olivia Siegl, for graciously sharing their data and information about the intervention. For feedback on earlier versions of the paper and analytical approach, we thank Leigh Raymond, Trenton Mize, and two anonymous reviewers. Data collection for this project was financially supported by a Leverhulme Trust to JPG Jones (RPG-2014-056) and a grant from the UK's Ecosystem Services and Poverty Alleviation programme to N Asquith (NE/L001470/1). N Asquith was also supported by a Charles Bullard Fellowship from Harvard Forest. A Purdue University PRF Summer Faculty Grant to T Grillos provided support for data analysis and manuscript preparation.

\footnotetext{
${ }^{1}$ Present address: Institute of Geography, University of Bern, Hallerstrassse, 12, 3012 Bern, Switzerland; patrick.bottazzi@giub.unibe.ch

${ }^{2}$ Present address: Cuencas Sustentables, Calle Río Totaitú 15, Barrio Las Palmas, Santa Cruz de la Sierra, Bolivia; nigelasquith@yahoo.com

${ }^{3}$ Present address: School of Natural Science, College of Environmental Sciences and Engineering, Thoday Building, Deniol Road, Bangor, LL57 2UW; julia.jones@bangor.ac.uk
} 


\section{In-kind Conservation Payments Crowd in Environmental Values and Increase Support for Government Intervention: \\ A Randomized Trial in Bolivia}

\section{ABSTRACT}

There is growing use of economic incentives such as Payments for Ecosystem Services (PES) to encourage sustainable land management. An important critique is that such approaches may unintentionally disrupt environmental and social values, 'crowding out' pre-existing motivations to conserve. Some scholars suggest that the use of in-kind payments and norm-based framing, rather than financial transfers and a market framing, can mitigate these risks. There are calls to use more robust methods for impact evaluation in environmental policy. We use one of the only Randomized Controlled Trials of a conservation incentive scheme to evaluate its impact on selfstated environmental and social values and beliefs. Data from before and after the intervention, from households in villages randomly selected to receive the program or not, demonstrate that the program increased prioritization of environmental values (evidence of crowding-in as opposed to crowding out) and altered social beliefs related to inequality and the role of government. The findings demonstrate that this conservation program had a positive impact on environmental values and increased the belief that government involvement is appropriate. The scheme, with its use of in-kind payments and reciprocity framing, offers lessons to those seeking to develop effective schemes to incentivize positive environmental stewardship.

61 Keywords: payments for ecosystem services; motivation crowding; social norms; framing;

62 environmental values; Bolivia 


\section{1. Introduction}

66 Payments for Ecosystem Services (PES) are voluntary transactions whereby land managers are

67 incentivized to carry out natural resource management actions believed to generate ecosystem

68 services for another group of users or society as a whole. PES schemes have proven to be a valuable

69 tool for promoting conservation in vulnerable and critically important ecosystems (Jayachandran

70 et al. 2017). This approach has been adopted worldwide (Kinzig et al. 2011; Pattanayak, Wunder

71 \& Ferraro 2010) with over 550 ongoing PES programs, representing around US\$36-42 billion in

72 transactions (Salzman et al. 2018).

74 A common critique of PES programs is that financial incentives may have adverse effects on pre-

75 existing motivations for conservation, including both environmental and social values and beliefs

76 (Rode, Gómez-Baggethun \& Krause 2015). In particular, critics view PES as engaging in

77 “commodity fetishism", reducing complex ecosystem functions to tradeable services (Kosoy \&

78 Corbera 2010, Muradian et al. 2010). A large body of social science research demonstrates that

79 financial incentives sometimes result in the opposite of their intended effect (Bowles 2008; Deci,

80 Koestner \& Ryan 1999; Frey 1994; Gneezy \& Rustichini 2000; Titmuss 1971). This phenomenon,

81 known as "motivation crowding", could potentially lead to a decrease in conservation behavior,

82 especially after the incentive payments end (Andersson et al. 2018). However, the original

83 psychology literature on motivation crowding suggests that external interventions can sometimes

84 enhance pre-existing motivations rather than displace them (crowding "in" rather than "out"), if

85 the external intervention is perceived as congruent with one's own values and identity (Deci,

86 Koestner \& Ryan 1999). 
88 Another, closely related critique of PES programs is that, in practice, they often present barriers to

89 entry that exclude the poorest members of communities (Bremer, Farley \& Lopez-Carr 2014;

90 Pagiola, Arcenas \& Platais 2005). Compensation programs often feature participation skewed

91 toward wealthier members of a community (Greig-Gran, Porras \& Wunder 2005; Zbinden \& Lee

92 2005), and there is a risk that PES schemes may exacerbate pre-existing inequalities between

93 landowners and others (García-Amado et al. 2011). The tension between equity and efficiency of

94 market-based mechanisms has been an important concern in the literature (Brown \& Adger 2007;

95 Landell-Mills 2002; Pascual et al. 2010; Wunder 2008). Some caution that a failure to consider

96 social equity can undermine environmental protection in the long-run through disenchantment with

97 the program (Pascual et al. 2014). These studies raise concerns about unintended social impacts

98 that may arise from PES programs, leading scholars to a call for greater inclusion of the poor in

99 PES (Farley \& Costanza 2010). They also raise questions about the potential for motivation

100 crowding with respect, not only to intrinsic environmental values, but also to pro-social values and

101 beliefs, especially as they relate to inequality.

102

103 Apart from direct material benefits provided to participants, policies and programmatic 104 interventions also have interpretive effects (Pierson 1993) which may shape participants' 105 "psychological predisposition to participate in public life" and perceptions of "their status in 106 relation to other citizens and government" (Mettler 2002, p.352). Studies of this dynamic 107 interaction, aka policy feedback, have largely been focused on social policy in the United States 108 and Europe (Béland 2010, Campbell 2012), with little attention to the developing country context, 109 where government policies often co-exist and overlap with programs implemented by international 
110 and non-governmental organizations. If PES influences the values and beliefs of community

111 members, this may have long-run implications not only for the specific conservation behavior it

112 was designed to influence, but also for subsequent policy efforts related to equity in the same

113 communities. This represents a potential spillover of motivation crowding to other areas of policy

114 intervention, and warrants attention to the influence of PES on beliefs and values related to

115 inequality and government intervention, in addition to environmental conservation.

117 The introduction to a recent special section on motivation crowding in Ecological Economics

118 (Ezzine-de-Blas et al. 2019) argued that particular programmatic design features of PES programs,

119 including for example payment type and communication, will influence the likelihood of crowding

120 in vs. crowding out, to the extent that they stimulate feelings of competence, autonomy, and

121 social/environmental relatedness. Prior laboratory research suggests that in-kind payments may be

122 less prone to crowding out than cash, likely because they evoke social norms rather than a "market

123 logic" (Heyman \& Ariely 2004). Scholars have suggested such in-kind payments may be more

124 effective in the application of PES (Kerr, Vardhan \& Jindal 2014, Chan et al. 2017) but this has

125 not been tested in a field-based experiment.

127 In addition, a growing literature suggests that simply framing an intervention in a particular way 128 can change how people react to it (Chong and Druckman 2007, Clot et al. 2017) and that the 129 effectiveness of a particular framing depends on pre-existing norms and beliefs (Andrews et al. 130 2013). One such pre-existing norm is reciprocity, or the relational notion that people should give 131 back to those who help them. Recent research exploring the drivers of environmental values has 132 shown that they can be driven by a perceived relationship with nature (Bremer et al. 2018, Chan 
133 et al. 2016, 2017). Reciprocity is considered one of several shared principles of moral psychology,

134 common across many cultures (Haidt 2007) and has been observed to motivate human behavior in 135 a variety of decision contexts (Axelrod \& Hamilton 1981; Falk \& Fischbacher 2006). Taken as a

136 whole, this suggests that the combination of in-kind compensation and reciprocity framing may

137 reduce the risks of motivation crowding in incentive schemes.

139 A blossoming literature has explored the psychological impact of PES, and PES-like, programs on 140 individuals, through their motivations, values, beliefs and internalized norms, with few consistent 141 results. This literature has included a range of methods including ethnographic analyses (Bose, 142 Garcia \& Vira 2019, Van Hecken et al. 2019), structured interviews (García-Amado, Pérez \& 143 García 2013), quasi-experimental approaches (Agrawal, Chhatre \& Gerber 2015; Chervier, Le 144 Velly \& Ezzine-de-Blas 2019), regression discontinuity designs (Alix-Garcia et al. 2018) and 145 framed field experiments (Andersson et al. 2018; Cook et al. 2019; Handberg \& Angelsen 2019; 146 Kaczan, Swallow \& Adamowicz 2019; Moros, Valez \& Corbera 2019, Kolinjivadi et al. 2019). 147 There is substantial interest in the use of Randomized Controlled Trials (RCTs) in conservation 148 (Ferraro \& Pattanayak 2006, Bayliss et al. 2015), where units are randomly allocated to receive an 149 intervention or not, as a robust method of impact evaluation (Banerjee \& Duflo 2009). RCTs 150 overcome many of the challenges of other approaches to allow causal inference (the ability to 151 conclude that the intervention resulted in the result observed). However, the use of randomized 152 trials is still very rare in the study of environmental management interventions (Ma et al. 2017). 153 There are only two published RCT evaluations of PES schemes (Jayachandran et al. 2017; Pynegar 154 et al. 2018) and none that examine psychological effects on the values and beliefs of participants. 
156 We present the results of the only Randomized Controlled Trial to date that measures the effects

157 of a conservation incentive scheme on environmental and social values and beliefs among 158 community members. In this paper, we experimentally evaluate the impact of a PES-like program, 159 called Watershared, that features two specific design features intended to reduce the risk of 160 motivation crowding: the use of in-kind payments and framing that references local reciprocity 161 norms. We use before and after data from households in communities randomly allocated to be 162 offered Watershared agreements (treatment communities) or not (control communities) to evaluate 163 the extent to which the scheme resulted in motivation crowding related to environmental and social 164 values and beliefs.

\section{2. Environmental and Social Values and Beliefs}

167 The theory of motivation crowding primarily focuses on how motivation for future behavior will 168 be affected after incentive programs end and the new, external motivation is no longer a direct 169 driver (Andersson et al. 2018). However, as they have not yet happened, future environmental 170 behaviors and the motivations behind them are difficult to observe directly. As a result, studies of 171 motivation crowding often focus instead on values and beliefs which are commonly understood to 172 be important precursors to motivations for pro-environmental behaviors. If PES and PES-like 173 programs affect motivations for future environmental behaviors, they likely do so through changes 174 to individual values and beliefs.

175

176 Terms such as values and beliefs can be used to mean subtly different things. Our goal is not to 177 contribute to the theoretical arguments relating to these definitions but to examine shifts in mental 178 assessments that people might make as the result of experiencing a PES or PES-like intervention, 
179 and which, in turn, could influence later motivations for environmental behavior. Values can be 180 understood as universally held guiding principles for decisions that people make in their lives

181 (Schwartz 1992, p.21), thus providing a direct precursor to motivations for behavior. Much of the

182 literature on motivations for environmental behavior, specifically, focuses on four key types of 183 values: (i) hedonic or short-term pleasure-seeking values, (ii) egoistic or market values, (iii)

184 altruistic or pro-social values and (iv) biospheric or environmental values (Steg \& DeGroot 2012,

185 Steg et al. 2014b). Given the importance of both environmental and social values in motivating 186 environmental behaviors (Rode, Gómez-Baggethun \& Krause 2015), there is a risk if either or 187 both are crowded out by financial incentives.

189 There is evidence that those who endorse either environmental or social values are typically more 190 motivated to engage in pro-environmental behaviors (Steg et al. 2014a, Steg et al. 2014b, Nordlund 191 \& Garvill 2002, Stern et al. 1995, Thogersen \& Olander 2002). However, it is well recognized that 192 values alone are insufficient to motivate action. In order to take action, people must not only place 193 value on something, but also hold related beliefs, for example believing that the thing they value 194 is affected through their own individual actions (Schwartz 1970, 1977, Stern et al. 1995). We 195 define a belief as "any proposition that is accepted as true" (Colman 2001, as cited in Kenter et al. 196 2015), which is broad enough to include both value-laden attitudes and norms, as well as mere 197 descriptive perceptions of the world. The particular beliefs we measure in this paper are those that 198 seem most directly related to PES interventions: perceptions of a trade-off between environmental 199 conservation and economic growth, and views on inequality and egalitarian norms (see Table 1). 200 These touch directly on the two primary critiques of mainstream PES: (i) that they may lead to 201 "commodity fetishism" whereby perceptions shift toward viewing the forest as an economic 
202 commodity, and (ii) that they may exacerbate inequalities in communities, with related impacts on

203 perceptions of those inequalities. The intervention we examine here made explicit efforts to avoid

204 these pitfalls through its use of in-kind incentives and reciprocity framing.

205

206 3. The Intervention: Watershared

207 In 2003 the non-governmental organization Fundación Natura Bolivia (Natura), in cooperation

208 with several municipal governments, began using in-kind incentives to encourage conservation in

209 the Andean region of Bolivia. Their program, now called Watershared, aims to slow deforestation

210 and maintain supplies of high quality water available to communities. The program provides

211 modest development support in exchange for avoiding deforestation and excluding livestock from

212 riparian forest. Natura first visited each treatment community to offer a series of information

213 sessions presenting their compensations as "reciprocal watershed agreements" and likening the

214 arrangements to existing reciprocity norms that are common in the region (Bétrisey \& Mager 2014;

215 Capuma 2007). The information sessions characterized the program as establishing a reciprocal

216 relationship between (i) Natura and those entering into the Watershared agreements, (ii) upstream

217 and downstream water users, as well as between (iii) human beings and the natural environment.

218 The original definition of PES involves buyers and sellers of services (Wunder 2007),

219 while Watershared simply incentivizes landowners to conserve their watersheds. However, the

220 intervention does involve "voluntary transactions between service users and service providers that

221 are conditional on agreed rules of natural resource management for generating offsite services"

222 (Wunder 2015) and so consideration of the Watershared scheme is relevant to those interested in

223 the design of conservation incentive schemes such as PES. As of 2016, 210,000 hectares of forest 
224 owned by 4,500 households were under some version of Natura's Watershared conservation 225 agreements (Asquith 2016).

226

227 In our study setting, households enrolling land in Watershared agreements were provided with 228 development projects with a value of $\$ 100$ (as a one-off enrollment bonus) plus a variable amount 229 (ranging from \$1-\$10) per hectare conserved, depending on the type of land and the rules they 230 agreed to follow, which could include restrictions on both deforestation and degradation due to 231 cattle grazing. Between the 1960s and early 2000s, deforestation in the Bolivian lowlands 232 increased from about $4.7 \times 10^{4}$ hectares/year to more than $2.9 \times 10^{5}$ hectares/year (Killeen et al. 233 2008). During the ten years prior to our baseline survey, deforestation in our specific study area 234 was approximately 4,147 hectares, with a mean deforestation rate of $1.2 \%$ per community (Wiik et 235 al. 2019). The goal of the Watershared program was to limit forest degradation, as well as

236 deforestation. In particular, the agreements targeted the issue of cattle grazing in the watershed, 237 which can lead to fecal contamination of the water source (Crane et al. 1983, Sunohara et al. 2012) 238 and creates risks for biodiversity (Stern et al. 2002).

240 Payments were made in the form of inputs for sustainable livelihoods, such as fruit trees, 241 beekeeping equipment, irrigation tubing, or barbed wire (to help enclose the cattle and keep them 242 away from the watershed). Agreements (for three years) were offered on an individual basis 243 (Pynegar et al. 2018). Previous research on Watershared found that take-up was determined by a 244 combination of financial and social characteristics, with poorer community members less able to 245 participate (Grillos 2017) and that those motivated by pro-nature instrumental motivations were 246 more likely to enroll land which resulted in additional conservation (Bottazzi et al. 2018). In this 
247 study, we examine whether experiencing the intervention has changed prioritization of 248 environmental and social values, and whether it affected self-stated agreement with normative 249 statements related to inequality and the environment.

\section{4. Research Design}

\section{$252 \quad 4.1$ A Randomized Controlled Trial in Bolivia}

253 The Watershared intervention we study here took the form of a randomized controlled trial within 254 the Río Grande Valles Cruceños (RG-VC) Natural Integrated Management Area. The RG-VC is a 255 mixed-use protected area, meaning that, while it is identified as an important ecosystem in need of 256 protection, the government also recognizes the rights of pre-existing forest dwellers to use their 257 own land as they deem appropriate. Natura identified 129 villages inside the RG-VC and 258 conducted a pre-intervention survey with households in all of those communities in late 2010.

259 After stratifying by municipality, village size and number of cattle in the community, they then 260 randomly selected 65 villages out of the original 129 included in the survey. ${ }^{4}$ Individuals in these 261 randomly selected villages were offered the opportunity to enroll their land in Watershared 262 agreements, while the remaining communities constituted a control group (Pynegar et al. 2018).

263 Five years later, in late 2015, we implemented a follow-up survey with the same households in all 264 villages (those that received the program as well as those that did not), generating a panel dataset 265 (Bottazzi et al. 2017). Two papers have been published using the RCT. Pynegar et al. (2018) 266 examined the impact of the intervention on water quality (in terms of E. coli contamination of 267 water used for human consumption) and found no impact. Wiik et al. (2019) showed that the

\footnotetext{
${ }^{4}$ The study sample originally involved 130 villages, but one of the randomly selected control villages later turned out to be located outside the designated study area, so the baseline survey was not conducted there and it was dropped from all analyses.
} 
268 intervention had limited impact on slowing deforestation (using the Global Forest Change data).

269 Ours is the first paper to make use of the household survey data related to this intervention.

270

271 The randomized design of the intervention eliminates concerns over selection bias (Duflo et al.

272 2007), and balance tests confirm that the treatment and control groups did not differ substantially

273 at the outset on neither demographic characteristics nor our key outcome variables (See Appendix

274 A). However, those sampled in the treatment group were less likely to be active members of the

275 community council (called the organización territorial de base, or "OTB”), which previous

276 research also cited as an important predictor of program take-up (Grillos 2017). We address this

277 issue in the analytic methods section.

278

$279 \quad$ 4.2 The Dataset

280 Two thousand, six hundred and one $(2,601)$ households were included in the pre-treatment baseline 281 survey. Of these, 55\% (1,443 households) reside in one of the 65 treatment villages, and the other $28245 \%(1,158)$ reside in one of the 64 control villages. Of those initially surveyed within treatment 283 villages, 38\% (548 households) took up Watershared agreements. Since some families live in one 284 community but simultaneously own land in another, there was a small amount of contamination in 285 the control group, with 32 (out of 1,158 control households) reporting they took up a Watershared 286 agreement. We directly address this two-sided noncompliance in the analytic methods section 287 below. The post-treatment endline resurveyed 1,672 of those covered in the baseline. Attrition was 288 due to a combination of people moving away (there is high rural depopulation in this part of 
Bolivia) and not being available. ${ }^{5}$ Attrition was not correlated with any of our key outcome variables, although the subset that was re-surveyed at endline did differ on some control variables. ${ }^{6}$

291 Of those households surveyed at both baseline and endline, 58\% (970 households) were in the 292 treatment group, and 38\% (548 households) of those had entered into Watershared agreements.

294 The full survey instrument is archived alongside the full dataset [dataset] (Bottazzi et al. 2017).

295 The full text of the particular questions we identified as measuring environmental and social values 296 and beliefs is included in the next section (translated into English). Some of these questions were 297 initially removed from the post-treatment survey because of concerns about the length of the 298 survey. Due to their scholarly interest, they were then reintroduced in the remaining surveys. For 299 this reason, the sample size for some of these analyses is much more limited than the full set of 300 households included in the more general survey. There were 333 households that received the full 301 set of all our values and beliefs questions at both baseline and endline (i.e. 666 observations in the 302 panel dataset), and $69 \%$ of these (231 households) were part of the randomly assigned treatment 303 group. Of those in the treatment group, 40\% (92 individuals) had taken up Watershared 304 agreements. Balance tests confirm that this smaller subsample is representative of the broader 305 study region based on statistics from the full baseline survey (See Appendix B). ${ }^{7}$

$307 \quad 4.3$ Outcome Measures: Values and beliefs

\footnotetext{
${ }^{5}$ In addition, some additional households were also picked up in the endline survey without having been included in the original baseline survey, but these do not figure into any of our analyses or tables and represent less than $3 \%$ of the total households with whom we made contact throughout this process.

${ }^{6}$ Attrition was associated with, on average, less cattle ownership, slightly fewer people in the household, and less OTB membership. See Appendix B for comparisons across subsets.

${ }^{7}$ The two groups did differ slightly in that the smaller sample (who received all the questions at endline) oversampled the treatment group relative to the true proportions $(69 \%$ of the households included in the values sub-sample resides in the treatment group villages).
} 
308 The survey included questions about demographic characteristics, assets, education and

309 livelihoods as well as questions relating to environmental and social values and beliefs. Table 1

310 includes the full text of the survey questions (translated from Spanish) used to construct our

311 outcome measures related to environmental and social values and beliefs.

(Original Spanish in Italics)

\begin{tabular}{|c|c|}
\hline Construct & Survey Question \\
\hline Values & $\begin{array}{l}\text { I'm going to present you with some values that may be taught to children in } \\
\text { the home. Of these values, can you choose the two that you think are the } \\
\text { most important? } \\
\text { (a) Independence, (b) Creativity, (c) Protecting the Environment, (d) } \\
\text { Sharing with Others, being altruistic (e) Obedience, (f) Being a Good } \\
\text { Student, (g) Being Successful } \\
\text { Voy a presentarle algunos valores que se puede enseñar a los niños en } \\
\text { casa. ¿De estos valores, puede elegir los dos que piensa que son los más } \\
\text { importantes? } \\
\text { (a) Independencia, (b) Creatividad, (c) Cuidar el medio ambiente, (d) } \\
\text { Compartir con los demás, ser altruisto, (e) Obediencia, (f) Ser un buen } \\
\text { estudiante, (g) Búsqueda del éxito }\end{array}$ \\
\hline Beliefs & $\begin{array}{l}\text { Now I will read some statements and I would like to know if you agree with } \\
\text { each one. There is no correct answer, I just want to know your opinion. } \\
\qquad[1=\text { completely disagree... 5= completely agree }] \\
\text { Ahora voy a leer unas afirmaciones y me gustaría saber si usted está de } \\
\text { acuerdo con cada una. No hay una respuesta correca, sólo quiero saber su } \\
\text { opinión sobre cada una de las afirmaciones. } \\
{[1=\text { completamente en desacuerdo... } 5=\text { completamente de acuerdo] }}\end{array}$ \\
\hline Environmental beliefs & $\begin{array}{l}\text { - "In order to improve quality of life, it is necessary to harm the } \\
\text { environment." ["Para mejorar las condiciones de vida, es necesario } \\
\text { dañar el medio ambiente."] } \\
\text { - "We can have higher economic incomes if we protect the } \\
\text { environment." [ "Podemos tener mejores ingresos económicos si } \\
\text { protegemos el medio ambiente"] }\end{array}$ \\
\hline Social beliefs & $\begin{array}{l}\text { - "It is the responsibility of the government to reduce income inequality } \\
\text { between people with a lot of money and people with little money." } \\
\text { "Es responsibilidad del gobierno reducer la desigualdad de ingresos } \\
\text { entre las personas con mucho dinero y las personas con poco dinero." }\end{array}$ \\
\hline
\end{tabular}


- "If a person works more than others, it's fair that they earn more money." [ "Si una persona trabaja más que otras personas, es justo que gane más dinero." ]

- "If a person earns more than others, they must share with the rest." ["Si una persona gane más que otras, tiene que compartir con los demás.”]

316 To measure the relative priority placed on environmental and social values, we included a question

317 in the survey that asked respondents to choose their top two priorities from a list of values that 318 could be taught to children in the home. Among this list of possible values were the options 319 "protecting the environment" (biospheric/environmental values) and "sharing with others" 320 (altruistic/pro-social values). Our outcome variables related to values were two binary variables: 321 whether an individual chose, respectively, protecting the environment (environmental values) or 322 sharing with others (social values), as one of their top two priorities. This question was adapted 323 for the local context from one that appeared on the World Values Survey questionnaire (Inglehart 324 et al. 2014).

325 While environmental values have been measured in variety of ways in the past (Dietz 2005), we

326 find this relative priority version of the question to be the most compelling for various reasons.

327 First, we believe it is less prone to social desirability bias. Since all of the values are potentially 328 viewed as socially desirable, asking about each one individually could lead participants to simply 329 state that all are important. Asking them to choose between them, however, forces them to identify 330 those that are of utmost priority, even if all could be seen as desirable. Second, this type of question 331 is likely more comparable across individuals. Likert-scales can be interpreted differently by 332 different people, as the dividing line between agreeing "completely" and "somewhat" is less 333 objectively obvious than what it means to prefer one thing to another. Finally, this type of measure

334 is theoretically supported by much of the literature on the link between values and environmental 335 behavior. Steg (2016) argues that the link between environmental values and related behaviors is 
336 mitigated when individuals are operating in a choice environment where competing values are also 337 at play. According to Schwartz, "attitudes and behavior are guided... by tradeoffs among 338 competing values that are implicated simultaneously" (1996, p.121). Values may be culturally 339 shared, but individuals prioritize those values differently, leading to different individual choices 340 and actions in practice (Steg et al. 2014b). Thus, it is an individual's relative prioritization of 341 values, not their absolute magnitude (which is difficult to measure in a comparable way across 342 individuals anyway) that is the relevant driver of environmental behaviors.

344 This approach is similar to the strategy employed by Agrawal, Chhatre \& Gerber (2015) in which

345 they ask respondents what reason is more important for conserving forests and force them to 346 choose between economic and environmental reasons. ${ }^{8}$ Our measurement strategy differs in that 347 it focuses specifically on values and includes a wider variety of values, based loosely on 348 categorizations provided by the previous literature on values. An implication of this measurement 349 strategy is that identification with one value is mechanically linked to the measure of others. Thus, 350 an increase in the prioritization of environmental values must, by necessity, correspond with a 351 decrease in the prioritization of other values. However, given the theoretical justification for a 352 focus on relative prioritization of values, rather than absolute agreement with them, we view this 353 as a design feature, rather than a bug, of our measurement strategy.

355 The survey also included five questions relating to environmental and social beliefs, asking 356 respondents to what extent they agreed with various statements. These were designed to assess

\footnotetext{
${ }^{8}$ Agrawal, Chhatre \& Gerber (2015) also mention in a footnote that they piloted a version of the question that allowed respondents to choose "both." When they did so, nearly all of the participants chose that option. This demonstrates the potential for social desirability bias in questions that do not require trade-offs between competing values.
} 
357 two main perceptions that were deemed likely to change as a result of a PES-like program, based 358 on the two major critiques in the literature identified earlier in this paper. The environmental beliefs

359 questions aim to assess people's perceptions of a trade-off between environmental conservation

360 (biospheric values) and economic growth (egocentric values). The social beliefs questions aimed 361 to gauge participants' views on inequality and egalitarian norms.

362

\section{4.4 Analytic Methods}

364 We assess the effects of the intervention on self-stated environmental and social values and beliefs 365 using a difference-in-differences analysis, comparing the change in relevant survey responses in

366 the treatment group to the change in those same questions in the control group (for all those who 367 answered the questions at both baseline and endline). This difference-in-differences approach is 368 preferable, because it does not assume that the treatment and control group would have been 369 identical absent the intervention, only that the trend would have been similar (Angrist \& Pischke 370 2008). The parallel trends assumption is often violated when there is some sort of selection bias 371 into the treatment group that is endogenous to the outcome variables (Besley \& Case 2000). 372 However, randomization into the treatment group solves the selection bias problem (Duflo \& 373 Kremer 2005). The combination of randomization with difference-in-differences is particularly

374 robust, as the randomization means there are likely to be no systematic differences in unobservable 375 characteristics of the sort that could violate the parallel trends assumption. The intervention was 376 cluster-randomized at the village level, but balance tests suggest that the treatment and control 377 group do not differ significantly with respect to most key variables at the household level (See 378 Appendix A). 
380 For the purpose of these analyses, the data were stacked, meaning they were structured as a panel 381 dataset, with two observations for each household: one from the pre-treatment (baseline) survey

382 and one from the post-treatment (endline) survey. For each model, we restrict the sample to only 383 those households who answered each question at both baseline and endline. In the basic difference-

384 in-differences model, each hypothesized effect of the intervention is regressed on a simple model 385 including three explanatory variables: a dummy for whether the observation was in the treatment 386 group or not, another indicating whether the observation was from the baseline or endline survey, 387 and finally, an interaction term between the treatment and endline variables. The coefficient on 388 this interaction term represents the effect of the intervention (Angrist \& Pischke 2008; Puhani 389 2012).

\section{4.4.1 Intent-to-Treat Approach}

392 To explore the effectiveness of the intervention as delivered to the whole population (ie comparing 393 those in the control communities to all those who were randomized into the treatment group 394 regardless of whether they entered into an agreement), we first ran basic intent-to-treat models. In 395 the equation below, we describe the basic linear version of our difference-in-differences models, 396 using an intent-to-treat approach. $Y_{i v t}$ is the outcome variable for person $i$ in village $v$ at time $t . D_{v}$ 397 represents the treatment, $T_{t}$ represents the post-treatment period, and the interaction term, $D_{v} \cdot T_{t}$ 398 takes on the value of 1 only for observations from the treatment group that were surveyed in the 399 post-treatment period. The coefficient $\delta$ is the estimator for our treatment effect: the difference 400 between the difference in the treatment group after the intervention and the difference in the control 401 group over the same time period. As treatment, endline and the interaction are included in the 402 model, the de facto reference category is individuals in the control group at baseline. 


$$
Y_{i v t}=\alpha+\beta D_{v}+\gamma T_{t}+\delta\left(D_{v} \cdot T_{t}\right)+\varepsilon_{i v t}
$$

404 While the equation above represents the basic linear model specification, our final models take the

405 form of either ordered logit (in the case of the categorical outcome variables) or logit (in the case 406 of the binary outcome variables) models, all with clustered standard errors by village. Results from 407 the basic intent-to-treat models can be found in Appendix C.

409 This basic intent-to-treat analysis applies the difference-in-differences analysis to a comparison of 410 the time trend between all observations in the control group and all observations in the treatment 411 group, including those who did not choose to sign up for agreements through the program. This is

412 an appropriate approach because we wish to understand the overall impact of the program 413 (including the effect of the offer itself and its likelihood to be adopted). It is also appropriate due 414 to the likelihood that there are spillover effects within the treatment group, whereby those who did 415 not directly participate as an agreement-holder might still be affected, for example through the 416 spread of social norms from those in their village who did participate or through the effect of the 417 information sessions delivered in all treatment villages.

419 In the case of the outcomes derived from the respondent's prioritization of environmental and 420 social values, we also include one additional covariate to capture some heterogeneity in the number 421 of responses offered. While the question asked the respondent to choose only the top two priorities, 422 in some cases enumerators allowed respondents to name three. Thus, we include a control variable 423 for the number of responses given, as this of course directly affects the likelihood of choosing any 424 particular option from the list. Unsurprisingly, this variable is highly significant as a predictor of 
425 choosing any particular response. Our main results are consistent whether this additional variable

426 is included or not. No other covariates are included in the main model described above.

428 4.4.2 Intent-to-Treat Plus Matching

429 The randomized nature of the program implementation should eliminate the need to include control

430 variables (Mutz 2011). However, because the subsample that received the values questions was

431 not randomly selected and did differ slightly from the broader sample, this introduces the

432 possibility that the members of the treatment and control groups who were included in the final

433 sample differ in some systematic way. Though we have no reason to suspect that there is selection

434 bias into this smaller sample that is systematically related to our outcomes of interest, we cannot

435 wholly rule it out. Thus, to address this possibility, we also include a matching analysis to further

436 confirm the validity of our results. While matching alone cannot guarantee causal inference, it may

437 be combined with traditional ITT estimates to strengthen confidence in the results (Sekhon 2009).

438 Using Stata's psmatch2 command and the mahalanobis distance matching specification with

439 replacement (Leuven \& Sianesi 2018), we identify matched pairs between the treatment and

440 control group. The mahalanobis distance matching uses a specified set of covariates from the

441 baseline survey, based on prior research into the key determinants of taking up the agreements

442 (Grillos 2017).

443

444 The covariates used in the matching include demographic controls (the age and education of the 445 head of household) as well as a combination of financial factors (formal land ownership, cattle

446 ownership, the number of rooms in the home, whether the household has alternative sources of 447 income apart from that derived from the land, whether anyone in the household has taken out loans 
448 in recent months, trust in institutions), community involvement (participation in community work 449 projects, generations living in the community, participation in the formal community decision450 making body), and environmental values (inability to identify forest benefits, whether they 451 prioritized environment as a value at baseline, and agreement with various statements about 452 environmental conservation). These covariates were used to identify a matched sample based on

453 baseline characteristics, which were then incorporated into the basic intent-to-treat regression 454 models using frequency weights. (Full output of the regression models based on the matched 455 sample can be found in Appendix E.)

\subsubsection{Instrumental Variables Approach (Take-up)}

458 The intent to treat model considers outcomes of all households in the treatment community the 459 same, regardless of whether they took up the treatment or not. However, if we believe that the 460 intervention should only have an effect on those who directly entered into Watershared 461 agreements, then it is appropriate to instead calculate the Complier Average Causal Effect 462 (CACE). In our case of two-sided noncompliance, one widely accepted method of estimating the 463 effect of the treatment on the treated is to use treatment assignment as an instrumental variable 464 predicting take-up (Gerber \& Green 2012; Glennerster \& Takavarasha 2013). Because treatment 465 assignment was randomly assigned and affects outcomes through its effect on actual treatment, it 466 is an ideal instrumental variable. It can be used to estimate the treatment effect through a two-stage 467 least squares regression process in which we estimate predicted take-up as a function of treatment 468 assignment, and then use that predicted take-up as the key predictor of our outcomes of interest. 
470 However, this approach assumes that the instrumental variable (treatment assignment) can only

471 affect outcomes through take-up of the Watershared agreements (Gerber \& Green 2012;

472 Glennerster \& Takavarasha 2013). Thus, this approach is likely inappropriate in the case of this

473 intervention, where treatment assignment means exposure to framed information sessions with

474 potential effects on those in the treatment group, even if they do not ultimately take up agreements.

475 We include the instrumental variables approach mainly as a robustness check related to the issue 476 of two-sided noncompliance. We apply it using Stata's ivregress command, specifying treatment 477 assignment as the instrument for agreement take-up. The instrumental variables regressions can be 478 found in Appendix D, and their results are consistent with those of our basic intent-to-treat models.

\section{$480 \quad 4.4 .4$ Predicted Probabilities and Other Robustness Checks}

481 Some scholars argue that, in logit models, interaction terms should not be interpreted the same 482 way as in other models, and that a statistically significant interaction term is neither necessary nor 483 sufficient for a true interaction to exist (Ai \& Norton 2003; Berry et al. 2010). Instead they 484 recommend focusing on predicted probabilities. To address this potential critique, for our two 485 binary outcome variables (relating to the prioritization of environmental and social values, 486 respectively), we also confirm our main results using predicted probabilities (Berry et al. 2010). 487 See Appendix $\mathrm{F}$ for the test of second differences confirming our finding with respect to 488 environmental values. Though not presented in the paper, we have also confirmed that results are 489 robust to the use of 2 or 3 nearest neighbors, as opposed to 1, to the application of the instrumental 490 variables regression to the matched dataset, and to a matched comparison of endline values only 491 as opposed to the difference-in-differences estimator. 
510 have resulted in 'crowding in' of environmental values. In addition, the intervention alters social

511 beliefs within the treated communities. It tends to support an individualistic and/or meritocratic

512 view as opposed to a more communalized model of local redistribution. At the same time, it also

513 increased the view that the government should play a direct role in addressing inequality. Below,

514 we discuss results with respect to each of our key outcome variables in more detail.

\subsection{Environmental Values \& Beliefs: Crowding in of Environmental Values}

517 Prior to the intervention, fewer than half $(\sim 41 \%)$ of respondents prioritized "protecting the 518 environment" as one of the most important values to teach their children. After the intervention, 519 people in the treatment group were more likely to prioritize environmental protection (Figure 1).

520 This result was both highly significant across all three model types and relatively large in 521 magnitude. The difference in differences is estimated to be 0.285 , meaning that the estimated effect 522 of the intervention was for an additional $\sim 28 \%$ of participants to prioritize environmental values 523 who previously did not. This demonstrates a "crowding in" of environmental values.

525 Figure 1 illustrates the shift in prioritization of environmental values. On the left-hand side, we 526 show (for the matched sample) the raw proportion of participants who rank environmental values

527 above others for (i) the control group, (ii) those in the treatment group who did not take up 528 agreements, and (iii) those in the treatment group who did take up agreements, both before and 529 after the intervention. This shows that the proportion prioritizing the environment increased in the 530 treatment group both for those with and without agreements, although the jump is larger for the 531 agreement-holders. On the right-hand side of Figure 1, we show the predicted proportions based 532 on the intent-to-treat model plus matching. It demonstrates that, on the whole, the intervention 
533 group increased their prioritization of environmental values to a statistically significant degree,

534 while the control group remained more or less constant.

535

536

537

538

539

540

541

542

543

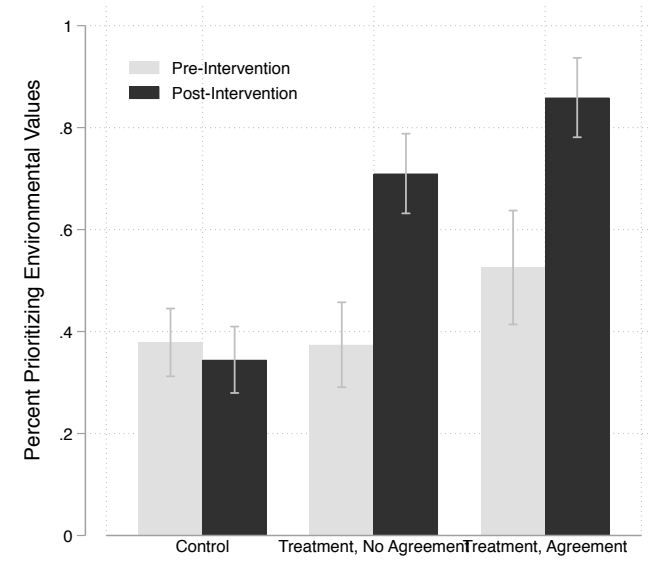

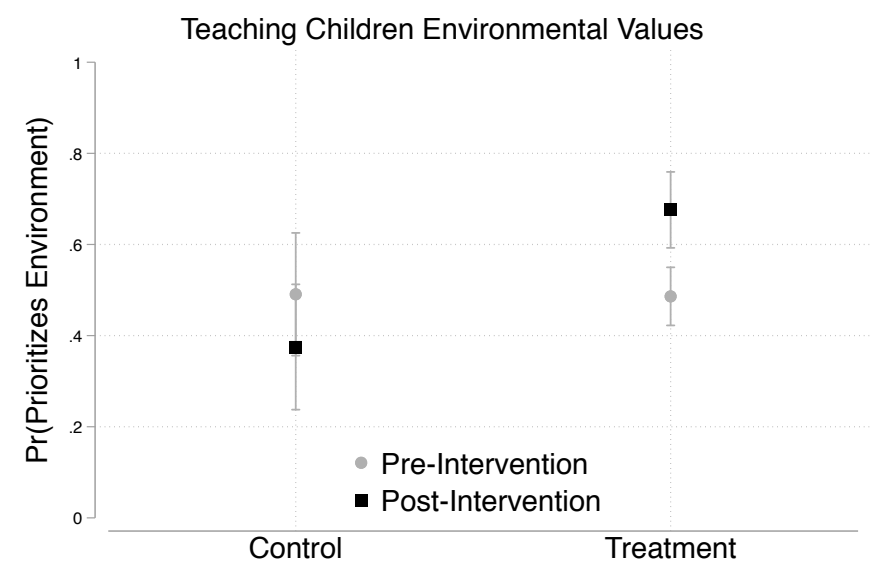

Figure 1: Prioritization of Environmental Values

(Left: Distribution of Raw Data -Matched Sample, Right: Predicted Probabilities from Matched Regression Model)

Descriptive statistics and visual inspection of the raw data suggest that the increase in prioritization

of environmental values occurred among both agreement-holders and non-agreement-holders in

the treatment group. Community members within the treatment villages who did not sign compensation agreements would still have received the informational components of the intervention, which the NGO delivered through community meetings as part of the initial program

544 offer. Thus, residents of the treatment villages would have been exposed to the reciprocity framing

545 even if they did not receive any compensation, and be subject to any socialization effects that could

546 arise from the communication alone.

548 With respect to environmental beliefs, there was no statistically significant effect on how likely a 549 person was to agree with the statements "To improve quality of life, it is necessary to harm the 550 environment" and "We can improve our incomes if we protect the environment". Most people in 551 both groups already strongly agreed with pro-environment statements at baseline (more than $75 \%$ 
552 choosing the most extreme pro-environmental position on a 5-point likert scale on each question)

553 and these opinions remained relatively stable over the period of the study.

554

555 5.2 Social Values \& Beliefs: Altered Beliefs on Inequality and Government Involvement

556 In the treatment group, there was a negative shift in the likelihood that a household prioritizes

557 sharing or altruism as a value to teach their children. This effect was statistically significant in two

558 of our three models, but it was not robust to the use of the matched sample. This implies that the

559 shift likely was related to particular characteristics of those sampled in the treatment group, rather

560 than a result of the intervention itself. We thus hesitate to put too much weight on this finding, but

561 it would be consistent with other results discussed below, including a regional trend toward

562 individualism, and the notion that the intervention may have strengthened or accelerated that

563 existing trend.

564

565 With respect to the first of the three questions on social beliefs, the intervention had no effect on

566 agreement with the statement "If a person earns more than others, they must share with the rest",

567 but more than $45 \%$ of people at baseline already disagreed or strongly disagreed with that

568 statement. That percentage increased to more than $70 \%$ in the treatment group after the

569 intervention but as disagreement increased in the control group as well, this effect was not

570 statistically significant and cannot be directly attributed to the intervention. In both the treatment

571 and control group, individuals are less likely at endline to favor the form of redistribution suggested

572 by this question. This may be interpreted as a general trend toward individualism across the region

573 over time (in both treatment and control groups), unrelated to the Watershared intervention. 
575 Relatedly, after exposure to the intervention, treated respondents were more likely to agree that "If

576 a person works more than others, it is fair that they earn more money" (Figure 2). This result was

577 statistically significant and consistent across all model specifications. While most people agreed

578 with this statement even at baseline, an increase in the percentage of people in the treatment group

579 stating that they "strongly agree" (the most extreme option on a 5-point Likert scale) is what drives

580 the change in the treatment group. This reflects an increased identification with the notion of

581 "meritocratic inequality." It suggests that the intervention may have further strengthened existing

582 trends toward individualism in the region, as evidenced by the result described in the previous

583 paragraph.
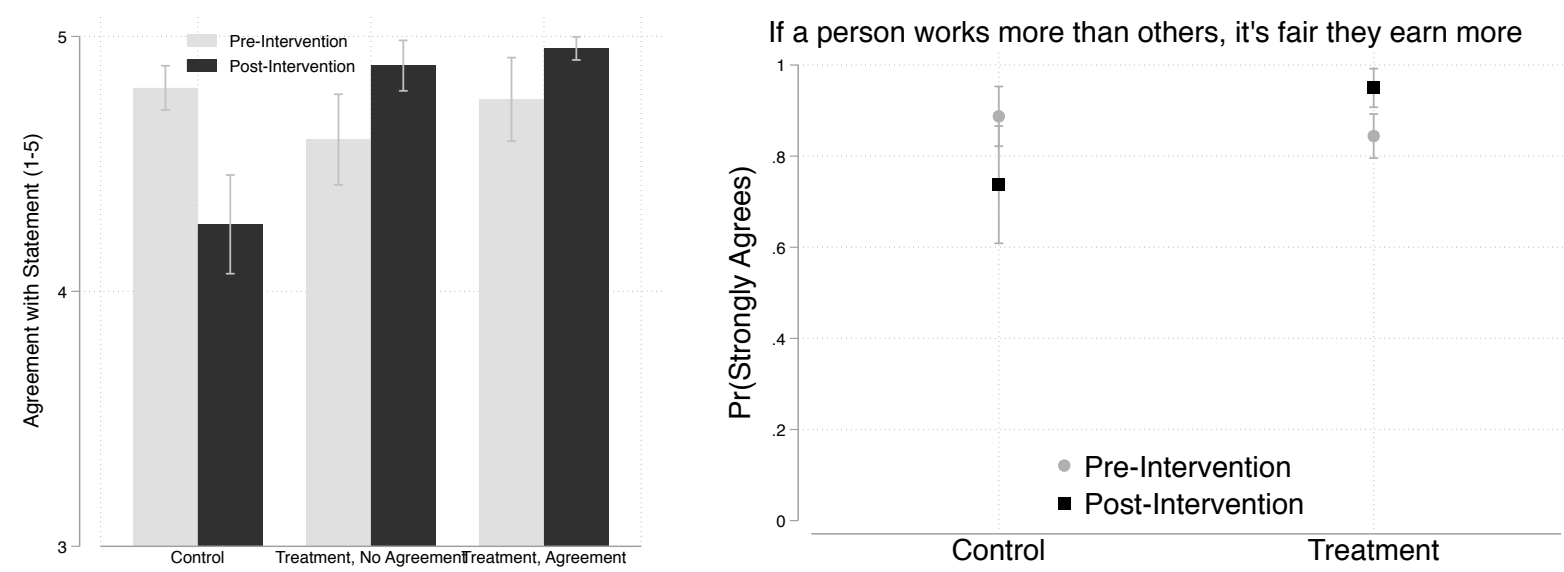

Figure 2: Agreement with Meritocratic Inequality

588 However, there was also a positive effect on agreement with the statement "It's the responsibility

589 of the government to reduce inequality of income between people with a lot of money and people

590 with a little money" (Figure 3). In the matching analysis with one nearest neighbor, the statistical

591 significance for this latter outcome drops but is still marginally significant $(p=0.069)$. (Using 2 or

5923 nearest neighbors, the $\mathrm{p}$ value is below 0.05.) This result with respect to government

593 responsibility moves in the opposite direction of the regional trend. (In the control group, support 
594 for government involvement decreases over this same time period.) We view this result as

595 demonstrating an increased belief that the social security net should be transferred from the

596 community to the government level. After experiencing this intervention (presented as a 597 government-NGO partnership), individuals in the treatment communities are more likely to 598 believe that the government should shoulder the responsibility for helping out the poor.
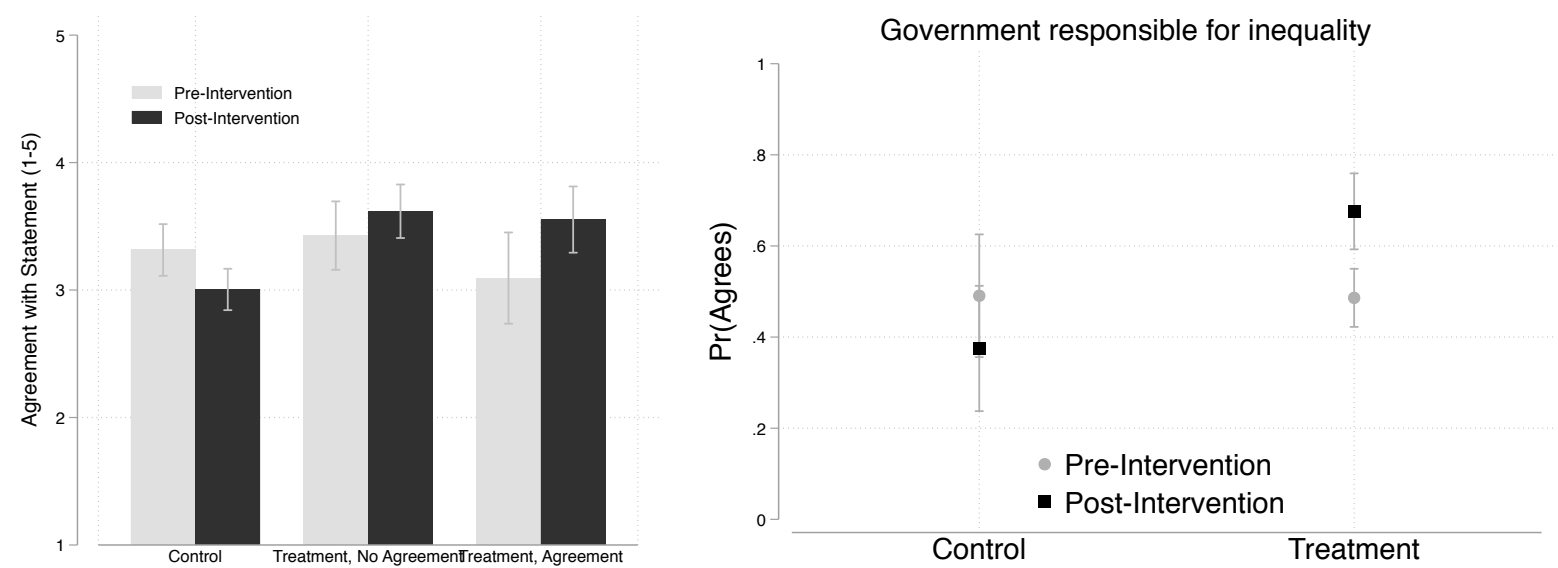

603 Respondents simultaneously felt that income inequalities cannot be the responsibility of local 604 villagers themselves, but that they must be dealt with somehow through government intervention.

605 Taken as a whole, we interpret these results as an indication that the treatment increased the 606 acceptability of government intervention with respect to income inequality, despite a strong 607 regional trend toward disagreement with redistribution in general. The treatment provoked a 608 change in local perception of distributional values, from a community-based system to a state609 based system. After exposure to the intervention (presented as a partnership with municipal 610 governments), respondents are more likely than the control group to agree with meritocratic 611 inequality but also to support the role of government in addressing inequalities. In general, the 
612 program had a countervailing effect on the overall regional trend toward individualism and limited

613 government involvement, by increasing the acceptability of government intervention.

614

615 6. Discussion

616 Understanding the effects of incentive programs like PES on environmental and social values is

617 important in order to improve the chances for such interventions to make deep and permanent

618 socio-ecological change toward more sustainable development. Two major concerns in the

619 literature have been (i) the risk of crowding out values that are supportive of conservation behavior

620 (Rode, Gómez-Baggethun \& Krause 2015, Ezzine-de-Blas et al. 2019) and (ii) the tension between

621 market-based efficiency and the equity of PES interventions (Pascual et al. 2010). Our study

622 speaks to both of these ongoing discussions.

623

624 First, our case illustrates that, contrary to fears around motivation crowding, Watershared had a

625 positive influence on self-stated pro-environmental values. Notably, this program influenced

626 environmental values even among those who did not receive any compensation. This suggests not

627 only that the program avoided the crowding out often associated with financial incentives, but that

628 it did so, at least in part, through the introductory information sessions, which included framing

629 related to reciprocity. This complements other literature which emphasizes the role of 'nudges', or

630 subtle contextual cues - as opposed to direct information about outcomes - in influencing

631 environmental behaviors (Thaler \& Sunstein 2008, Ölander \& Thogersen 2014). Since framed

632 information sessions are generally inexpensive relative to other programmatic design features, this

633 also represents a promising and cost-effective approach for policy-makers. 
635 Our results also illustrate that the scheme had influences on social beliefs. The program was

636 associated with an increased acceptance of 'meritocratic inequality' but also increased support for

637 government involvement in reducing inequality. Prior work demonstrated that barriers to entry

638 (such as a lack of formal land title) limit the ability of the poorest community members to

639 participate in this program (Grillos 2017), echoing concerns in the PES literature that barriers to

640 entry could potentially exacerbate pre-existing inequalities. But our results here show that even

641 among those in the treatment group who have not entered into Watershared agreements, the shift

642 in social beliefs moves in the same direction. That is to say, people who have not directly benefitted

643 from the compensations (but have been exposed to the reciprocity framing) also strongly agree

644 with the meritocratic inequality statement and simultaneously favor government action on

645 inequality. This echoes another recent study which concluded that payments programs based on

646 meritocratic principles need not be in conflict with equity (Loft et al. 2019).

647

648 Our results with respect to views on the role of government could, at first glance, be interpreted as

649 increased support for redistribution, but our other results contradict the notion that there is support

650 for direct redistribution between people within the community. (Most people in both the treatment

651 and control group disagree that individuals are obligated to share their wealth.) Instead this result

652 seems to speak directly to views about the government itself. This intervention was conducted as

653 a collaborative effort between Natura and several municipal governments. (Though the municipal

654 governments did not directly contribute funds in the early years of the intervention during which

655 these data were collected, the program was always presented to the communities as being

656 conducted in partnership with the municipal government.) As a result of this quasi-governmental

657 intervention, people's views of government and its role have been altered. Contrary to concerns in 
658 the literature that disenchantment with program-related inequalities may decrease support for later

659 efforts, in this case we find that there may in fact be greater support for future governmental policy

660 interventions as a result of this particular program.

661

662 The use of a Randomized Controlled Trial to evaluate impacts of this program lends increased

663 internal validity to our study, providing one of the clearest examples of causal inference in this

664 literature to date. However, there are of course still limitations associated with our research design

665 that we wish to acknowledge here. First, the use of self-stated data on values and beliefs is limited

666 by social desirability bias and experimenter demand effects, in that respondents may say what they

667 believe researchers want to hear (Tourangeau et al. 2000). This is somewhat mitigated by the fact

668 that we collect pre- and post- intervention data in both treatment and control groups (since social

669 desirability bias is likely to be at play across all interviews), and the research team made efforts to

670 ensure that the interviewers were not seen as affiliated with the NGO (while Natura did manage

671 the initial hiring of the enumerators, the unaffiliated researchers trained and supervised them).

672 Second, given that this experiment spanned multiple years, we cannot completely rule out the

673 possibility of spillover effects. If control communities heard about incentive programs in other

674 villages, they may perceive that others have opportunities to earn more to which they have not had

675 access - thus decreasing their degree of comfort with the notion of meritocratic inequality. This is

676 of particular concern for the meritocratic inequality finding, since a corresponding decrease in

677 agreement in the control group contributes to the statistical significance of the result.

678

679 Our results contrast with other prior studies that found evidence of motivation crowding in 680 conservation incentive programs (Agrawal, Chhatre \& Gerber 2015; Chervier, Le Velly \& Ezzine- 
de-Blas 2019; García-Amado, Pérez \& García 2013; Moros, Valez \& Corbera 2019), and

682 corroborate arguments that fears of motivation crowding in PES may be overstated (Andersson et

683 al. 2018; Handberg \& Angelsen 2019; Kaczan, Swallow \& Adamowicz 2019). However, we are

684 cautious in generalizing these results to other incentive programs, as we believe contrasting results

685 are due to differences in specific design features. In particular, we believe the use of in-kind

686 compensation, individual-level agreements, and the targeted framing related to local reciprocity

687 norms all likely influenced the results we present here.

689 As described earlier, there is reason to believe that both the use of in-kind payments and norm-

690 based framing may reduce the risk of crowding out. Here we demonstrate that these design features

691 may go even farther, leading to a crowding in of environmental values. At the same time, the

692 reciprocity framing may also have influenced results with respect to social beliefs. One

693 interpretation of reciprocity is an expectation of fair exchange, including potentially that of reward

694 for effort. ${ }^{9}$ The Natura information sessions evoked reciprocity not only with respect to human-

695 environment relations generally but also specifically with respect to the compensations earned

696 through the conservation agreements. If framing successfully engaged internalized reciprocity

697 norms with respect to environmental protection, then perhaps it also led individuals to feel more

698 entitled to the goods earned through the agreements - and therefore more comfortable with any

699 potentially unequal distribution resulting from it.

\footnotetext{
${ }^{9}$ This interpretation is distinct from alternative definitions of reciprocity in, for example, the anthropological literature, which views reciprocity not as a direct exchange of goods and services, but rather as an indirect and delayed system of exchange based on trust and internal cohesion.
} 
701 Finally, Watershared involves individual land owners entering into agreements. Several studies

702 have suggested that individual payments have different psychological implications for motivation

703 crowding compared with communal payments (Agrawal, Chhatre \& Gerber 2015; Kerr, Vardhan

704 and Jindal 2014; Midler et al. 2015; Moros, Vélez and Corbera 2019; Narloch, Pascual and Drucker

705 2012). A recent paper found that communal payments in Mexico had a positive impact on social

706 capital (Alix-Garcia et al. 2018). Programs directed at entire communities may eliminate barriers

707 faced by non-landowners, but on the other hand, community-based management programs are in

708 practice often co-opted by local elites, potentially also resulting in elite capture of benefits

709 (Bardhan \& Mookherjee 2000; Iversen et al. 2006). Even if payments are not skewed within

710 communities, they may influence inequality across groups, with benefits accruing

711 disproportionately to wealthier communities relative to the additionality of their conservation

712 (Murtinho \& Wolff 2015). On the other hand, individual agreements can increase the perception

713 of individual rights to natural resources and, as observed here, influence local attitudes toward

714 more individualism. We thus recommend caution in assuming that the same results may be found

715 in communal payment settings.

716

\section{$717 \quad 5.1$ Conclusions}

718 Our results are supportive of the continued use of incentives to promote conservation, and they

719 highlight a particular approach that has successfully increased pro-environmental values (these

720 show 'crowding-in' as opposed to 'crowding out'). We also provide relatively robust evidence

721 about how a carefully designed incentive scheme may influence the perspectives of community

722 members themselves, potentially affecting the acceptance and effectiveness of future policy

723 efforts. This work contributes to a large body of social science research about how the form in 
724 which incentives and information are delivered can shape human perceptions and values and

725 thereby subsequent policy intervention. It also engages with a growing, policy-relevant literature

726 on psychology and environmental behavior.

727 


\section{Works Cited}

729 Agrawal, A., Chhatre, A. \& Gerber, E. R. 2015. Motivational crowding in sustainable development interventions. 2015. American Political Science Review 109, 470-487

731 Ai, C., \& Norton, E. C. 2003. Interaction terms in logit and probit models. Economics letters, 80(1), 123-129

Alix-Garcia, J. M., Sims, K. R., Orozco-Olvera, V. H., Costica, L. E., Medina, J. D. F., \& Monroy, S.R. 2018. Payments for environmental services supported social capital while increasing land management. Proceedings of the National Academy of Sciences,

Andersson, K., Cook, N., Grillos, T., Lopez, MC., Salk, C., Wright, G.D. \& Mwangi, E. 2018. Experimental Evidence on Payments for Forest Commons Conservation. Nature Sustainability 1(3).

Andrews, A. C., Clawson, R. A., Gramig, B. M., \& Raymond, L. 2013. Why do farmers adopt conservation tillage? An experimental investigation of framing effects. Journal of Soil and Water Conservation, 68(6), 501-511.

Angrist, J. D., \& Pischke, J. S. 2008. Mostly Harmless Econometrics: An empiricist's companion.

745 Asquith NM. 2016. Watershared: Adaptation, mitigation, watershed protection and economic development in Latin America. Climate \& Development Knowledge Network.

747 Axelrod, R., \& Hamilton, W. D. 1981. The evolution of cooperation. Science, 211(4489), 13901396.

749 Banerjee, A. V., \& Duflo, E. 2009. The experimental approach to development economics. Annu. Rev. Econ., 1(1), 151-178. 
751 Bardhan, P. K., \& Mookherjee, D. 2000. Capture and governance at local and national levels. American Economic Review, 90(2), 135-139.

753 Baylis, K., Honey-Rosés, J., Börner, J., Corbera, E., Ezzine-de-Blas, D., Ferraro, P. J., ... \&

Béland, D. 2010. Reconsidering policy feedback: How policies affect politics. Administration \& Wunder, S. 2016. Mainstreaming impact evaluation in nature conservation. Conservation Letters, 9(1), 58-64. Society, 42(5), 568-590.

Berry, W. D., DeMeritt, J. H., \& Esarey, J. 2010. Testing for interaction in binary logit and probit models: Is a product term essential? American Journal of Political Science, 54(1), $248-266$.

Besley, Timothy and Anne Case. 2000. Unnatural Experiments? Estimating the Incidence of Endogenous Policies, Economic Journal, 110(467), F672-F694.

Bétrisey, F., \& Mager, C. 2014. Small Farmers in Florida Province, Bolivia: reciprocity in practice. Mountain Research \& Development 34 (4), 369-374.

Bose, Arshiya, Claude Garcia, and Bhaskar Vira. 2019. Mottled motivations and narrow incentives: Exploring limitations of direct incentive policies in the Western Ghats, India. Ecological Economics, 156: 454-467.

Bottazzi, P., Wiik, E., Crespo, D., \& Jones, J. P. 2018. Payment for Environmental “SelfService": Exploring the Links Between Farmers' Motivation and Additionality in a Conservation Incentive Programme in the Bolivian Andes. Ecological Economics, 150, 11-23.

Bottazzi, Patrick and Maria Teresa Vargas Rios, Nigel Asquith, David Crespo, Tito Vidaurre, Máximo García, Rafael Miler Guzmán, Lucindo Gonzales, Hugo Vallejos, Basilio Pérez 
Guzman, Fidel Avila Becerra, Dionicio Toledo, Julio Cesar García, James M Gibbons,

775

776

777

778

779

780 Benigno Mojica García, Johnny Severiche, Edgar Talavera, Edgar Velásquez, and Julia P G Jones. (2017). Baseline and endline socio-economic data from a Randomized Control Trial of the Watershared intervention in the Bolivian Andes. [Data Collection]. Colchester, Essex: UK Data Archive. 10.5255/UKDA-SN-852623

Bowles, S. 2008. Policies designed for self-interested citizens may undermine" the moral sentiments": Evidence from economic experiments. Science, 320(5883), 1605-1609.

Bremer, L. L., Farley, K. A., \& Lopez-Carr, D. 2014. What factors influence participation in payment for ecosystem services programs? An evaluation of Ecuador's SocioPáramo program. Land Use Policy, 36, 122-133.

Bremer, L. L., Brauman, K. A., Nelson, S., Prado, K. M., Wilburn, E., \& Fiorini, A. C. O. (2018). Relational values in evaluations of upstream social outcomes of watershed Payment for Ecosystem Services: a review. Current opinion in environmental sustainability.

Campbell, A. L. 2012. Policy makes mass politics. Annual Review of Political Science,15:333351.

Capuma, E.C. 2007. El Ayni: un paradigma de sistema cultural indígena. Ulinku, Oruro. Chan, Kai M.A., Patricia Balvanera, Karina Benessaiah, Mollie Chapman, Sandra Díaz, Erik Gómez-Baggethun, Rachelle Gould, Neil Hannahs, Kurt Jax, Sarah Klain, Gary W Luck, Berta Martín-López, Barbara Muraca, Bryan Norton, Konrad Ott, Unai Pascual, Terre Satterfield, Marc Tadaki, Jonathan Taggart, and Nancy Turner. 2016. Why protect nature? Rethinking values and the environment. Proceedings of the National Academy of Sciences, 113(6): 1462-1465. 
797 Chan, Kai M.A., Emily Anderson, Mollie Chapman, Kristjan Jespersen, \& Paige Olmsted. 2017.

798 Payments for Ecosystem Services: Rife with Problems and Potential - For

799 Transformation Towards Sustainability. Ecological Economics, 140: 110-122.

800 Chan, Kai MA, Rachelle K Gould \& Unai Pascual. 2018. Editorial overview: Relational values:

801 what are they, and what's the fuss about? Current Opinion in Environmental

$802 \quad$ Sustainability 35: A1-A7.

803 Chervier, C., Le Velly, G. \& Ezzine-de-Blas, D. 2019. When the Implementation of Payments

804 for Biodiversity Conservation Leads to Motivation Crowding-out: A Case Study From

805 the Cardamoms Forests, Cambodia. Ecological Economics, 156: 499-510.

806 Chong, D., \& Druckman, J. N. 2007. Framing theory. Annual Review of Political

807 Science, 10:103-126.

808 Clot, S., G. Grolleau and P. Méral, 2017. Payment Vs. Compensation For Ecosystem Services:

809 Do Words Have A Voice In The Design of Environmental Conservation Programs?

$810 \quad$ Ecological Economics 135: 299-303

811 Colman Andrew, M. 2001. Oxford Dictionary of Psychology.

812 Cook, N. J., Grillos, T., \& Andersson, K. P. (2019). Gender quotas increase the equality and 813 effectiveness of climate policy interventions. Nature Climate Change, 1.

814 Corbera, E., Brown, K., \& Adger, W. N. 2007. The equity and legitimacy of markets for 815 ecosystem services. Development and change, 38(4), 587-613.

816 Crane, S. R., Moore, J. A., Grismer, M. E., \& Miner, J. R. 1983. Bacterial pollution from 817 agricultural sources: a review. Transactions of the American Society of Agricultural $818 \quad$ Engineers, 26(3), 858-0866. 
819 Deci EL, Koestner R, \& Ryan RM. 1999. A meta-analytic review of experiments examining the effects of extrinsic rewards on intrinsic motivation. Psychological Bulletin 125(6):62768.

822 Dietz, T., Fitzgerald, A., \& Shwom, R. 2005. Environmental values. Annual Review of Environmental Resources, 30, 335-372.

824 Duflo, E., Glennerster, R., \& Kremer, M. 2007. Using randomization in development economics research: A toolkit. Handbook of development economics, 4, 3895-3962.

Duflo, E., \& Kremer, M. 2005. Use of randomization in the evaluation of development effectiveness. Evaluating development effectiveness, 7, 205-231.

Ezzine-de-Blas, D., E. Corbera and R. Lapeyre. 2019. Payments for Environmental Services and Motivation Crowding: Towards a Conceptual Framework. Ecological Economics, 156,

831 Falk, A., \& Fischbacher, U. 2006. A theory of reciprocity. Games and economic behavior, 54(2), 293-315.

833 Farley, J., \& Costanza, R. 2010. Payments for ecosystem services: from local to global. Ecological economics, 69(11), 2060-2068.

835 Ferraro, P. J., \& Pattanayak, S. K. 2006. Money for nothing? A call for empirical evaluation of biodiversity conservation investments. PLoS biology, 4(4), e105.

837 Frey BS. 1994. How intrinsic motivation is crowded out and in. Rationality and Society, $6(3): 334-352$.

839 García-Amado, L. R., Pérez, M. R., Escutia, F. R., García, S. B., \& Mejía, E. C. 2011. Efficiency of payments for environmental services: equity and additionality in a case study from a biosphere reserve in Chiapas, Mexico. Ecological Economics, 70(12), 2361-2368. 
842 García-Amado LR, Pérez MR, \& García SB. 2013. Motivation for conservation: Assessing 843 integrated conservation and development projects and payments for environmental services in La Sepultura Biosphere Reserve, Chiapas, Mexico. Ecological Economics 89:92-100.

Gerber, A. S., \& Green, D. P. 2012. Field experiments: Design, analysis, and interpretation.

Glennerster, R., \& Takavarasha, K. 2013. Running randomized evaluations: A practical guide. Princeton University Press.

Gneezy U \& Rustichini A. 2000. Pay enough or don't pay at all. Quarterly Journal of Economics

Grieg-Gran, M., Porras, I., \& Wunder, S. 2005. How can market mechanisms for forest 115(3):791-810.

Grillos, T. 2017. Economic vs. Non-Material Incentives for Participation in an In-Kind Payments for Ecosystem Services Program in Bolivia. Ecological Economics, 131: 178-190.

Haidt, J. (2007). The new synthesis in moral psychology. Science, 316(5827), 998-1002. forest experiment in Tanzania. Ecological Economics, 156: 454-467. Economics, 118, 81-89. 
865 Inglehart, R., C. Haerpfer, A. Moreno, C. Welzel, K. Kizilova, J. Diez-Medrano, M. Lagos, P. Norris, E. Ponarin \& B. Puranen et al. (eds.). 2014. World Values Survey: Round Six Country-Pooled Datafile 2010-2014. Madrid: JD Systems Institute.

868 Iversen, V., Chhetry, B., Francis, P., Gurung, M., Kafle, G., Pain, A., \& Seeley, J. 2006. High value forests, hidden economies and elite capture: Evidence from forest user groups in Nepal's Terai. Ecological economics, 58(1), 93-107.

871 Jayachandran, S., De Laat, J., Lambin, E. F., Stanton, C. Y., Audy, R., \& Thomas, N. E. 2017. 872 Cash for carbon: A randomized trial of payments for ecosystem services to reduce 873 deforestation. Science, 357(6348), 267-273.

874 Kaczan, D., Swallow, B.M, \& Adamowicz, W.L. 2019. Forest conservation policy and motivational crowding: Experimental evidence from Tanzania. Ecological Economics, 156: 444-453.

877 Kenter, J. O., O'Brien, L., Hockley, N., Ravenscroft, N., Fazey, I., Irvine, K. N., Reed, MS, Christie, M., Brady, E., Bryce, R., Church, A., Cooper, N., Davies, A., Evely, A., Everard, M., Fish, R., Fisher, JA., Jobstvogt, N., Molloy, C., Orchard-Webb, J., Ranger, S., Ryan, M., Watson, V., \& Williams, S. 2015. What are shared and social values of ecosystems? Ecological Economics, 111, 86-99.

882 Kerr, J., Vardhan, M., \& Jindal, R. 2014. Incentives, conditionality and collective action in 883 payment for environmental services. International Journal of the Commons, 8(2).

884 Kinzig, A. P., Perrings, C., Chapin, F. S., Polasky, S., Smith, V. K., Tilman, D., \& Turner, B. L. 885 2011. Paying for ecosystem services_- promise and peril. Science, 334(6056), 603-604. 
886 Kolinjivadi, Vijay, Simon Charré, Jan Adamowski \& Nicolás Kosoy. 2019. Economic Experiments for Collective Action in the Kyrgyz Republic: Lessons for Payments for Ecosystem Services (PES). Ecological Economics, 156: 489-498.

889

Kosoy, N. and E. Corbera. 2010. Payments for ecosystem services as commodity fetishism. Ecological economics 69(6): 1228-1236.

Landell-Mills, N. 2002. Developing markets for forest environmental services: an opportunity for promoting equity while securing efficiency? Philosophical Transactions of the Royal Society of London A: Mathematical, Physical and Engineering Sciences, 360(1797):1817-1825.

Leuven, Edwin and Sianesi, Barbara. 2018. PSMATCH2: Stata module to perform full Mahalanobis and propensity score matching, common support graphing, and covariate imbalance testing, https://EconPapers.repec.org/RePEc:boc:bocode:s432001.

Loft, L., Gehrig, S., Le, D. N., \& Rommel, J. (2019). Effectiveness and equity of Payments for Ecosystem Services: Real-effort experiments with Vietnamese land users. Land Use Policy, 86, 218-228.

Ma, Z., Bauchet, J., Steele, D., Godoy, R., Radel, C., \& Zanotti, L. 2017. Comparison of direct transfers for human capital development and environmental conservation. World Development, 99, 498-517.

Mettler, S. (2002). Bringing the state back in to civic engagement: Policy feedback effects of the GI Bill for World War II veterans. American Political Science Review, 96(2), 351-365.

Midler, E., Pascual, U., Drucker, A. G., Narloch, U., \& Soto, J. L. 2015. Unraveling the effects of payments for ecosystem services on motivations for collective action. Ecological Economics, 120: 394-405. 
909 Moros, L., Velez, M.A., \& Corbera, E. 2019. Payments for Ecosystem Services and Motivational

910 Crowding in Colombia’s Amazon Piedmont. Ecological Economics, 156: 468-488.

911 Muradian, R., E. Corbera, U. Pascual, N. Kosoy and P. H. May. 2010. Reconciling theory and

912 practice: an alternative conceptual framework for understanding payments for

913 environmental services. Ecological Economics 69: 1202-1208.

914 Mutz, D. C. 2011. Population-based survey experiments. Princeton University Press.

915 Narloch, U., Pascual, U., \& Drucker, A. G. 2012. Collective Action Dynamics under External

$916 \quad$ Rewards: Experimental Insights from Andean Farming Communities. World

917 Development.

918 Nordlund AM, Garvill J. 2002. Value structures behind pro-environmental behavior. Environ.

$919 \quad$ Behav. 34:740-56

920 Ölander, F. \& Thogersen, J. 2014. Informing Versus Nudging in Environmental Policy. Journal

921 of Consumer Policy. 37(3), 341-356.

922 Pagiola, S., Arcenas, A., \& Platais, G. 2005. Can payments for environmental services help

923 reduce poverty? An exploration of the issues and the evidence to date from Latin

$924 \quad$ America. World development, 33(2), 237-253.

925 Pascual, U., Muradian, R., Rodríguez, L. C., \& Duraiappah, A. 2010. Exploring the links

926 between equity and efficiency in payments for environmental services: a conceptual

927 approach. Ecological Economics, 69(6), 1237-1244.

928 Pascual, U., Phelps, J., Garmendia, E., Brown, K., Corbera, E., Martin, A., Erik Gomez-

929 Baggethun, and Muradian, R. 2014. Social equity matters in payments for ecosystem

$930 \quad$ services. Bioscience 64, no. 11 2014: 1027-1036. 
931 Pattanayak, S. K., Wunder, S. \& Ferraro, P. J. 2010. Show Me the Money: Do Payments Supply

932 Environmental Services in Developing Countries? Review of Environmental Economics $933 \quad$ and Policy 4: 254-274.

934 Pierson, Paul. 1993. When Effect Becomes Cause: Policy Feedback and Political Change. World 935 Politics 45(4): 595-628.

936 Puhani, P. A. 2012. The treatment effect, the cross difference, and the interaction term in 937 nonlinear “difference-in-differences” models. Economics Letters, 115(1), 85-87.

938 Pynegar, E. L., Jones, J. P., Gibbons, J. M., \& Asquith, N. M. 2018. The effectiveness of

939 Payments for Ecosystem Services at delivering improvements in water quality: lessons 940 for experiments at the landscape scale. PeerJ, 6, e5753.

941 Rode, J., Gómez-Baggethun, E., \& Krause, T. 2015. Motivation crowding by economic 942 incentives in conservation policy: A review of the empirical evidence. Ecological 943 Economics, 117, 270-282.

944 Salzman, J., Bennett, G., Carroll, N., Goldstein, A., \& Jenkins, M. 2018. The global status and 945 trends of Payments for Ecosystem Services. Nature Sustainability, 1(3), 136.

946 Schwartz, S. H. 1970. Moral decision making and behavior. In J. Macauley \& L. Berkowitz 947 (Eds.), Altruism and helping behavior (pp. 127-141). New York, NY: Academic.

948 Schwartz, S. H. 1977. Normative influences on altruism. In L. Berkowitz (Ed.), Advances in 949 experimental social behavior (Vol. 10, 22 1-279). New York, NY: Academic.

950 Schwartz, S. H. 1992. Universals in the content and structure of values: Theoretical advances and 951 empirical tests in 20 countries. In Advances in experimental social psychology (Vol. 25, 952 pp. 1-65). Academic Press. 
953 Schwartz S. 1996. Value priorities and behavior: applying a theory of integrated value systems.

954 In The Psychology of Values, ed. C Seligman, JM Olson, MP Zanna, pp. 1-24. Mahwah, 955 NJ: Erlbaum Assoc

956 Sekhon, J. S. 2009. Opiates for the matches: Matching methods for causal inference. Annual 957 Review of Political Science, 12, 487-508.

958 Steg, L. 2016. Values, norms, and intrinsic motivation to act proenvironmentally. Annual Review 959 of Environment and Resources, 41, 277-292.

960 Steg, L., \& de Groot, J. I. 2012. Environmental values. In The Oxford handbook of

961 environmental and conservation psychology, ed. S Clayton, pp.81-92. New York: Oxford $962 \quad$ University Press.

963 Steg, L., Bolderdijk, J. W., Keizer, K., \& Perlaviciute, G. 2014. An integrated framework for 964 encouraging pro-environmental behaviour: The role of values, situational factors and 965 goals. Journal of Environmental psychology, 38, 104-115.

966 Steg L, Perlaviciute G, Van der Werff E, Lurvink J. 2014. The significance of hedonic values for 967 environmentally-relevant attitudes, preferences and actions. Environmental Behavior. 968 46(2):163-92

969 Stern, M., Quesada, M., \& Stoner, K. E. 2002. Changes in composition and structure of a tropical 970 dry forest following intermittent cattle grazing. Revista de Biología Tropical, 50(3-4), $971 \quad$ 1021-1034.

972 Stern, PC, Dietz T, Kalof L, Guagnano G. 1995. Values, beliefs and pro-environmental action:

973 Attitude formation toward emergent attitude objects. Journal of Applied Social $974 \quad$ Psychology, 25, 1611-36. 
975 Stern, P. C., Dietz, T., Abel, T., Guagnano, G. A., \& Kalof, L. 1999. A value-belief-norm theory 976 of support for social movements: The case of environmentalism. Human ecology review, $977 \quad 81-97$

978 Sunohara, M. D., Topp, E., Wilkes, G., Gottschall, N., Neumann, N., Ruecker, N., ... \& Marti, R. 979 2012. Impact of riparian zone protection from cattle on nutrient, bacteria, F-coliphage, 980 Cryptosporidium, and Giardia loading of an intermittent stream. Journal of 981 environmental quality, 41(4), 1301-1314.

982 Tallis, H. \& Lubchenco, J. 2014. A call for inclusive conservation: petition for an end to the 983 infighting that is stalling progress in protecting the planet. Nature, $515(7525), 27-28+$.

984 Thaler, R. \& Sunstein, C. 2008. Nudge: Improving Decisions About Health, Wealth and 985 Happiness. Penguin Books: New York.

986 Thøgersen, J., \& Ölander, F. 2002. Human values and the emergence of a sustainable 987 consumption pattern: A panel study. Journal of economic psychology, 23(5), 605-630.

988 Titmuss R. 1971. The Gift Relationship: From Human Blood to Social Policy. New York: 989 Pantheon Books.

990 Tourangeau, R., Rips, L.J., Rasinski, K., 2000. The Psychology of Survey Response. Cambridge 991

992 Van Hecken, G., Merlet, P., Mara, L., \& Bastiaensen, J. 2019. Can Financial Incentives change 993 Farmers' Motivations? An Agrarian System Approach to Development Pathways at the

995 Wiik, E., d'Annunzio, R., Pynegar, E., Crespo, D., Asquith, N., \& Jones, J. P. (2019).

996 Experimental evaluation of the impact of a payment for environmental services program 997 on deforestation. Conservation Science and Practice, 1(2), e8. 
998 Wunder, S. 2007. The Efficiency of Payments for Environmental Services in Tropical

999 Conservation. Conservation Biology, 21(1), 48-58.

1000 Wunder, S. 2008. Payments for environmental services and the poor: concepts and preliminary

1001 evidence. Environment and development economics, 13(3), 279-297.

1002 Wunder, S. 2015. Revisiting the concept of payments for environmental services. Ecological

1003 Economics, 117, 234-243.

1004 Zbinden, S., \& Lee, D. R. 2005. Paying for environmental services: an analysis of participation

1005 in Costa Rica's PSA program. World development, 33(2), 255-272.

1006

Appendix

1007 A. Balance Tests - Treatment vs. Control (based on full baseline survey)

1008

\begin{tabular}{|lrrrrr|}
\hline & $\begin{array}{r}\text { Control } \\
\text { Mean }\end{array}$ & SD & Treated & & \\
Eean & SD & p-value \\
"Mnironmental Values \& Beliefs: & & & & & \\
"Must harm environment to improve life" (1-5) & 1.41 & 1.02 & 1.45 & 1.07 & 0.355 \\
Prioritizes environment as value for kids & 4.63 & .85 & 4.60 & .90 & 0.449 \\
Social Values \& Beliefs: & .38 & .49 & .40 & .49 & 0.346 \\
"Earn more, must share with others" (1-5) & & & & & \\
"Work more, should earn more" (1-5) & 2.83 & 1.72 & 2.81 & 1.71 & 0.716 \\
"Government responsible address inequality" (1-5) & 4.69 & .89 & 4.63 & .98 & 0.119 \\
Prioritizes sharing and altruism as value & 3.44 & 1.51 & 3.43 & 1.54 & 0.810 \\
Demographic Controls: & .25 & .43 & .22 & .42 & $0.084^{+}$ \\
Age Head of Household & & & & & \\
Educational Level & 49.87 & 16.37 & 49.36 & 16.37 & 0.429 \\
People in Household & 4.65 & 3.47 & 4.82 & 3.67 & 0.225 \\
OTB Membership & 3.50 & 1.88 & 3.50 & 1.81 & 0.960 \\
Hectares of Land Owned & .84 & .37 & .76 & .42 & $0.000^{* * *}$ \\
Cattle Ownership & 25.43 & 61.77 & 26.58 & 63.04 & 0.644 \\
Number of Cattle & .69 & .46 & .69 & .46 & 0.753 \\
Perceptions of Current Situation: & 12.09 & 22.60 & 11.41 & 17.65 & 0.384 \\
Forest better than 5 years ago & & & & & \\
Community care better than 5 years ago & 2.19 & .81 & 2.22 & .82 & 0.350 \\
& 1.97 & .77 & 2.03 & .77 & $0.026^{*}$
\end{tabular}




\begin{tabular}{llllll|} 
Both water quality \& quantity is a problem & .20 & .40 & .23 & .42 & 0.137 \\
All victims of problem & .87 & .33 & .90 & .30 & $0.051^{+}$ \\
All contribute to solution & .75 & .43 & .78 & .42 & 0.205 \\
& & & & & \\
Total Observations (exact n varies by variable) & 1,158 & & 1,443 & & \\
\hline
\end{tabular}

1009

${ }^{+} p<0.1,{ }^{*} p<0.05,{ }^{* *} p<0.01,{ }^{* * *} p<0.001$

1010

1011 
B. Balance Tests - Included vs Excluded from Analyses (based on baseline survey)

\begin{tabular}{|c|c|c|c|c|c|c|c|c|}
\hline \multirow[b]{2}{*}{ Environmental Values \& Beliefs: } & \multicolumn{2}{|c|}{ All Baseline } & \multicolumn{3}{|c|}{ Re-surveyed only } & \multicolumn{3}{|c|}{ Values Questions Subset } \\
\hline & Mean & sd & Mean & $\mathrm{sd}$ & p-value & Mean & $\mathrm{sd}$ & p-value \\
\hline "Must harm environment to improve life" (1-5) & 1.43 & 1.05 & 1.43 & 1.06 & 0.797 & 1.48 & 1.12 & 0.414 \\
\hline "Environment improves incomes" (1-5) & 4.62 & .88 & 4.62 & .88 & 0.651 & 4.63 & .87 & 0.770 \\
\hline Prioritizes environment as value for kids. & .39 & .49 & .40 & .49 & 0.126 & .41 & .49 & 0.427 \\
\hline \multicolumn{9}{|l|}{ Social Values \& Beliefs: } \\
\hline "Earn more, must share with others" (1-5) & 2.82 & 1.72 & 2.80 & 1.70 & 0.472 & 2.89 & 1.73 & 0.435 \\
\hline "Work more, should earn more" (1-5) & 4.66 & .94 & 4.64 & .98 & 0.266 & 4.64 & .97 & 0.675 \\
\hline "Government responsible address inequality"(1-5) & 3.43 & 1.52 & 3.44 & 1.53 & 0.654 & 3.32 & 1.57 & 0.148 \\
\hline Prioritizes sharing and altruism as value & .24 & .42 & .24 & .42 & 0.991 & .23 & .42 & 0.796 \\
\hline \multicolumn{9}{|l|}{ Demographic Controls: } \\
\hline Age Head of Household & 49.59 & 16.37 & 49.62 & 15.44 & 0.909 & 49.27 & 16.69 & 0.700 \\
\hline Educational Level & 4.74 & 3.58 & 4.85 & 3.54 & $0.053^{+}$ & 4.84 & 3.58 & 0.589 \\
\hline People in Household & 3.50 & 1.84 & 3.66 & 1.78 & $0.000^{* * *}$ & 3.43 & 1.76 & 0.457 \\
\hline OTB Membership & .80 & .40 & .82 & .39 & $0.001^{* *}$ & .78 & .41 & 0.411 \\
\hline Hectares of Land Owned & 26.07 & 62.46 & 26.85 & 64.10 & 0.399 & 32.36 & 84.57 & $0.051^{+}$ \\
\hline Cattle Ownership & .69 & .46 & .75 & .43 & $0.000^{* * *}$ & .69 & .46 & 0.952 \\
\hline Number of Cattle & 11.71 & 20.00 & 13.10 & 21.42 & $0.000^{* * *}$ & 13.68 & 24.97 & 0.055 \\
\hline \multicolumn{9}{|l|}{ Perceptions of Current Situation: } \\
\hline Forest better than 5 years ago & 2.20 & .81 & 2.22 & .81 & 0.148 & 2.19 & .83 & 0.805 \\
\hline Community care better than 5 years ago & 2.00 & .77 & 1.99 & .77 & 0.232 & 1.97 & .77 & 0.433 \\
\hline Both Water quality \& quantity is a problem & .22 & .41 & .22 & .41 & 0.751 & .20 & .40 & 0.367 \\
\hline All victims of problem & .89 & .32 & .89 & .31 & 0.863 & .86 & .35 & 0.150 \\
\hline All contribute to solution & .76 & .42 & .76 & .42 & 0.915 & .76 & .42 & 0.969 \\
\hline \multicolumn{9}{|l|}{ Treatment: } \\
\hline Treatment Group & .55 & .50 & .58 & .49 & $0.000^{* * *}$ & .69 & .46 & $0.000^{* * *}$ \\
\hline Agreement-Holder (Treatment Group only) & .38 & .49 & .47 & .50 & $0.000^{* * *}$ & .40 & .49 & 0.528 \\
\hline Total Observations (exact $\mathrm{n}$ varies by variable) & \multicolumn{2}{|c|}{2,601} & \multicolumn{3}{|c|}{1,672} & \multicolumn{3}{|c|}{333} \\
\hline
\end{tabular}




\section{Basic Intent to Treat Regressions: Environmental \& Social Values \& Beliefs}

\begin{tabular}{|c|c|c|c|c|c|c|c|}
\hline & \multicolumn{3}{|c|}{ Environmental Beliefs \& Values } & \multicolumn{4}{|c|}{ Social Beliefs \& Values } \\
\hline & $\begin{array}{l}(1) \\
\text { "Must harm } \\
\text { environment } \\
\text { to improve } \\
\text { life" }\end{array}$ & $\begin{array}{c}(2) \\
\text { "Environment } \\
\text { improves } \\
\text { incomes" }\end{array}$ & $\begin{array}{l}\text { (3) } \\
\text { Prioritizes } \\
\text { environment } \\
\text { as value for } \\
\text { kids }\end{array}$ & $\begin{array}{l}\text { (4) } \\
\text { "Earn more, } \\
\text { should share } \\
\text { with others" }\end{array}$ & $\begin{array}{c}(5) \\
\text { "Work more, } \\
\text { should earn } \\
\text { more" }\end{array}$ & $\begin{array}{l}(6) \\
\text { "Government } \\
\text { responsible } \\
\text { address } \\
\text { inequality" }\end{array}$ & $\begin{array}{c}\text { (7) } \\
\text { Prioritizes } \\
\text { sharing/ } \\
\text { altruism as } \\
\text { value for kids }\end{array}$ \\
\hline TreatmentEndline & $\begin{array}{l}-0.157 \\
(0.182)\end{array}$ & $\begin{array}{r}-0.0281 \\
(0.189)\end{array}$ & $\begin{array}{l}0.881^{* *} \\
(0.328)\end{array}$ & $\begin{array}{c}0.326 \\
(0.338)\end{array}$ & $\begin{array}{l}1.971^{* * *} \\
(0.564)\end{array}$ & $\begin{array}{c}0.608^{*} \\
(0.304)\end{array}$ & $\begin{array}{l}-0.724^{*} \\
(0.362)\end{array}$ \\
\hline Treatment & $\begin{array}{c}0.00526 \\
(0.151)\end{array}$ & $\begin{array}{c}0.196 \\
(0.143)\end{array}$ & $\begin{array}{c}0.391 \\
(0.257)\end{array}$ & $\begin{array}{l}-0.0223 \\
(0.279)\end{array}$ & $\begin{array}{l}-0.106 \\
(0.330)\end{array}$ & $\begin{array}{c}-0.00324 \\
(0.239)\end{array}$ & $\begin{array}{l}-0.109 \\
(0.286)\end{array}$ \\
\hline Endline & $\begin{array}{c}0.279^{*} \\
(0.138)\end{array}$ & $\begin{array}{c}-0.287^{+} \\
(0.158)\end{array}$ & $\begin{array}{c}0.00453 \\
(0.259)\end{array}$ & $\begin{array}{c}-0.863^{* * *} \\
(0.262)\end{array}$ & $\begin{array}{l}-0.560^{+} \\
(0.291)\end{array}$ & $\begin{array}{l}-0.416^{*} \\
(0.199)\end{array}$ & $\begin{array}{c}0.378 \\
(0.273)\end{array}$ \\
\hline NumResponses & & & $\begin{array}{l}0.919^{* * *} \\
(0.187)\end{array}$ & & & & $\begin{array}{l}1.144^{* * *} \\
(0.227)\end{array}$ \\
\hline Constant & & & $\begin{array}{c}-2.450^{* * *} \\
(0.435) \\
\end{array}$ & & & & $\begin{array}{c}-3.379^{* * *} \\
(0.518) \\
\end{array}$ \\
\hline $\mathrm{c} 1$ & $\begin{array}{l}1.458^{* * *} \\
(0.117)\end{array}$ & $\begin{array}{c}-3.352^{* * *} \\
(0.147)\end{array}$ & & $\begin{array}{c}-0.757^{* *} \\
(0.238)\end{array}$ & $\begin{array}{c}-2.996^{* * *} \\
(0.268)\end{array}$ & $\begin{array}{c}-1.662^{* * *} \\
(0.202)\end{array}$ & \\
\hline c2 & $\begin{array}{c}2.300^{* * *} \\
(0.135)\end{array}$ & $\begin{array}{c}-2.884^{* * *} \\
(0.143)\end{array}$ & & $\begin{array}{l}0.0185 \\
(0.240)\end{array}$ & $\begin{array}{c}-2.585^{* * *} \\
(0.302)\end{array}$ & $\begin{array}{c}-0.902^{* * *} \\
(0.183)\end{array}$ & \\
\hline c3 & $\begin{array}{l}2.791^{* * *} \\
(0.151)\end{array}$ & $\begin{array}{c}-2.354^{* * *} \\
(0.122)\end{array}$ & & $\begin{array}{c}0.162 \\
(0.245)\end{array}$ & $\begin{array}{c}-2.344^{* * *} \\
(0.285)\end{array}$ & $\begin{array}{l}-0.174 \\
(0.162)\end{array}$ & \\
\hline $\mathrm{c} 4$ & $\begin{array}{l}3.527^{* * *} \\
(0.191)\end{array}$ & $\begin{array}{c}-1.177^{* * *} \\
(0.116)\end{array}$ & & $\begin{array}{l}1.214^{* * *} \\
(0.250)\end{array}$ & $\begin{array}{c}-1.703^{* * *} \\
(0.279)\end{array}$ & $\begin{array}{l}0.968^{* * *} \\
(0.169)\end{array}$ & \\
\hline Observations & 3290 & 3290 & 642 & 666 & 664 & 662 & 642 \\
\hline
\end{tabular}

Standard errors in parentheses 
D. Instrumental Variable Regression: Environmental \& Social Values \& Beliefs

${ }^{+} p<0.1,{ }^{*} p<0.05,{ }^{* *} p<0.01,{ }^{* * *} p<0.001$
onmental $\&$ Social Values \& Beliefs

\begin{tabular}{|c|c|c|c|c|c|c|c|}
\hline & \multicolumn{3}{|c|}{ Environmental Beliefs \& Values } & \multicolumn{4}{|c|}{ Social Beliefs \& Values } \\
\hline & (1) & (2) & (3) & (4) & $(5)$ & (6) & (7) \\
\hline & $\begin{array}{l}\text { "Must harm } \\
\text { environment to } \\
\text { improve life" }\end{array}$ & $\begin{array}{l}\text { "Environment } \\
\text { improves } \\
\text { incomes" }\end{array}$ & $\begin{array}{l}\text { Prioritizes } \\
\text { environment } \\
\text { as value for } \\
\text { kids } \\
\end{array}$ & $\begin{array}{l}\text { "Earn more, } \\
\text { should share } \\
\text { with others" }\end{array}$ & $\begin{array}{l}\text { "Work more, } \\
\text { should earn } \\
\text { more" }\end{array}$ & $\begin{array}{c}\text { "Government } \\
\text { responsible } \\
\text { address } \\
\text { inequality" }\end{array}$ & $\begin{array}{c}\text { Prioritizes } \\
\text { sharing/ } \\
\text { altruism as } \\
\text { value for kids }\end{array}$ \\
\hline TakeUp & $\begin{array}{l}-0.143 \\
(0.181)\end{array}$ & $\begin{array}{r}-0.0195 \\
(0.188)\end{array}$ & $\begin{array}{c}0.543^{*} \\
(0.231)\end{array}$ & $\begin{array}{c}0.187 \\
(0.692)\end{array}$ & $\begin{array}{l}1.806^{* * *} \\
(0.454)\end{array}$ & $\begin{array}{c}1.491^{*} \\
(0.608)\end{array}$ & $\begin{array}{l}-0.440^{*} \\
(0.196)\end{array}$ \\
\hline Treatment & $\begin{array}{c}0.0134 \\
(0.0646)\end{array}$ & $\begin{array}{c}0.0535 \\
(0.0481)\end{array}$ & $\begin{array}{c}0.0933 \\
(0.0600)\end{array}$ & $\begin{array}{c}-0.0514 \\
(0.216)\end{array}$ & $\begin{array}{r}-0.0827 \\
(0.109)\end{array}$ & $\begin{array}{c}-0.0570 \\
(0.173)\end{array}$ & $\begin{array}{l}-0.0194 \\
(0.0522)\end{array}$ \\
\hline Endline & $\begin{array}{l}-0.0195 \\
(0.0669)\end{array}$ & $\begin{array}{l}-0.0879 \\
(0.0726)\end{array}$ & $\begin{array}{l}0.00419 \\
(0.0620)\end{array}$ & $\begin{array}{c}-0.719^{* * *} \\
(0.205)\end{array}$ & $\begin{array}{c}-0.412^{* * *} \\
(0.125)\end{array}$ & $\begin{array}{l}-0.330^{+} \\
(0.178)\end{array}$ & $\begin{array}{c}0.105^{*} \\
(0.0534)\end{array}$ \\
\hline NumResponses & & & $\begin{array}{l}0.184^{* * *} \\
(0.0332)\end{array}$ & & & & $\begin{array}{l}0.229^{* * *} \\
(0.0407)\end{array}$ \\
\hline Constant & $\begin{array}{l}1.424^{* * *} \\
(0.0531)\end{array}$ & $\begin{array}{l}4.590^{* * *} \\
(0.0417)\end{array}$ & $\begin{array}{c}-0.0161 \\
(0.0840)\end{array}$ & $\begin{array}{c}2.922^{* * *} \\
(0.185)\end{array}$ & $\begin{array}{l}4.693^{* * *} \\
(0.0890)\end{array}$ & $\begin{array}{c}3.360^{* * *} \\
(0.128)\end{array}$ & $\begin{array}{c}-0.205^{*} \\
(0.0927)\end{array}$ \\
\hline Observations & 3290 & 3290 & 642 & 666 & 664 & 662 & 642 \\
\hline
\end{tabular}

Note: The use of the matched sample combined with the instrumental variable regression produces results consistent with this table, except that the coefficient on "prioritizes sharing" is no longer significant. 


\section{E. Matching Analysis (Nearest Neighbors=1): Environmental \& Social Values \& Beliefs}

\begin{tabular}{|c|c|c|c|c|c|c|c|}
\hline & \multicolumn{3}{|c|}{ Environmental Beliefs \& Values } & \multicolumn{4}{|c|}{ Social Beliefs \& Values } \\
\hline & (1) & $(2)$ & (3) & $(4)$ & $(5)$ & (6) & $(7)$ \\
\hline & $\begin{array}{l}\text { "Must harm } \\
\text { environment to } \\
\text { improve life" }\end{array}$ & $\begin{array}{c}\text { "Environment } \\
\text { improves } \\
\text { incomes" }\end{array}$ & $\begin{array}{l}\text { Prioritizes } \\
\text { environment } \\
\text { as value for } \\
\text { kids } \\
\end{array}$ & $\begin{array}{l}\text { "Earn more, } \\
\text { should share } \\
\text { with others" }\end{array}$ & $\begin{array}{c}\text { "Work more, } \\
\text { should earn } \\
\text { more" }\end{array}$ & $\begin{array}{l}\text { "Government } \\
\text { responsible } \\
\text { address } \\
\text { inequality" }\end{array}$ & $\begin{array}{c}\text { Prioritizes } \\
\text { sharing/ } \\
\text { altruism as } \\
\text { value for kids }\end{array}$ \\
\hline TreatmentEndline & $\begin{array}{l}-0.239 \\
(0.222)\end{array}$ & $\begin{array}{l}-0.144 \\
(0.226)\end{array}$ & $\begin{array}{l}1.246^{* *} \\
(0.392)\end{array}$ & $\begin{array}{c}0.136 \\
(0.421)\end{array}$ & $\begin{array}{l}2.280^{* * *} \\
(0.682)\end{array}$ & $\begin{array}{c}0.672^{+} \\
(0.369)\end{array}$ & $\begin{array}{l}-0.330 \\
(0.427)\end{array}$ \\
\hline Treatment & $\begin{array}{c}0.188 \\
(0.165)\end{array}$ & $\begin{array}{c}0.177 \\
(0.174)\end{array}$ & $\begin{array}{c}0.182 \\
(0.313)\end{array}$ & $\begin{array}{c}0.188 \\
(0.301)\end{array}$ & $\begin{array}{l}-0.375 \\
(0.378)\end{array}$ & $\begin{array}{l}0.0299 \\
(0.343)\end{array}$ & $\begin{array}{c}-0.0512 \\
(0.357)\end{array}$ \\
\hline Endline & $\begin{array}{c}0.377^{*} \\
(0.186)\end{array}$ & $\begin{array}{l}-0.233 \\
(0.196)\end{array}$ & $\begin{array}{l}-0.338 \\
(0.361)\end{array}$ & $\begin{array}{l}-0.632^{+} \\
(0.370)\end{array}$ & $\begin{array}{l}-1.032^{*} \\
(0.486)\end{array}$ & $\begin{array}{l}-0.431 \\
(0.304)\end{array}$ & $\begin{array}{c}0.122 \\
(0.401)\end{array}$ \\
\hline NumResponses & & & $\begin{array}{l}1.002^{* * *} \\
(0.256)\end{array}$ & & & & $\begin{array}{l}0.927^{* *} \\
(0.282)\end{array}$ \\
\hline Constant & & & $\begin{array}{c}-2.462^{* * *} \\
(0.554) \\
\end{array}$ & & & & $\begin{array}{c}-2.984^{* * *} \\
(0.620) \\
\end{array}$ \\
\hline $\mathrm{c} 1$ & $\begin{array}{l}1.720^{* * *} \\
(0.130)\end{array}$ & $\begin{array}{c}-3.341^{* * *} \\
(0.194)\end{array}$ & & $\begin{array}{l}-0.463^{+} \\
(0.276)\end{array}$ & $\begin{array}{c}-3.264^{* * *} \\
(0.305)\end{array}$ & $\begin{array}{c}-1.699^{* * *} \\
(0.317)\end{array}$ & \\
\hline $\mathrm{c} 2$ & $\begin{array}{l}2.552^{* * *} \\
(0.153)\end{array}$ & $\begin{array}{c}-2.951^{* * *} \\
(0.174)\end{array}$ & & $\begin{array}{c}0.210 \\
(0.285)\end{array}$ & $\begin{array}{c}-2.955^{* * *} \\
(0.331)\end{array}$ & $\begin{array}{l}-0.910^{* *} \\
(0.313)\end{array}$ & \\
\hline c3 & $\begin{array}{c}2.972^{* * *} \\
(0.175)\end{array}$ & $\begin{array}{c}-2.447^{* * *} \\
(0.161)\end{array}$ & & $\begin{array}{c}0.376 \\
(0.282)\end{array}$ & $\begin{array}{c}-2.743^{* * *} \\
(0.334)\end{array}$ & $\begin{array}{c}-0.0724 \\
(0.285)\end{array}$ & \\
\hline $\mathrm{c} 4$ & $\begin{array}{l}3.701^{* * *} \\
(0.216) \\
\end{array}$ & $\begin{array}{c}-1.285^{* * *} \\
(0.152)\end{array}$ & & $\begin{array}{l}1.498^{* * *} \\
(0.278)\end{array}$ & $\begin{array}{l}-2.064^{* * *} \\
(0.334)\end{array}$ & $1.031^{\text {** }}(0.318)$ & \\
\hline Observations & 3564 & 3560 & 836 & 864 & 864 & 864 & 836 \\
\hline
\end{tabular}

Note: Using 2 or 3 nearest neighbors rather than 1 produces results consistent with this table (and increases statistical significance in model 6.) 


\section{F. Test of Second Differences: Prioritization of Environmental Values}

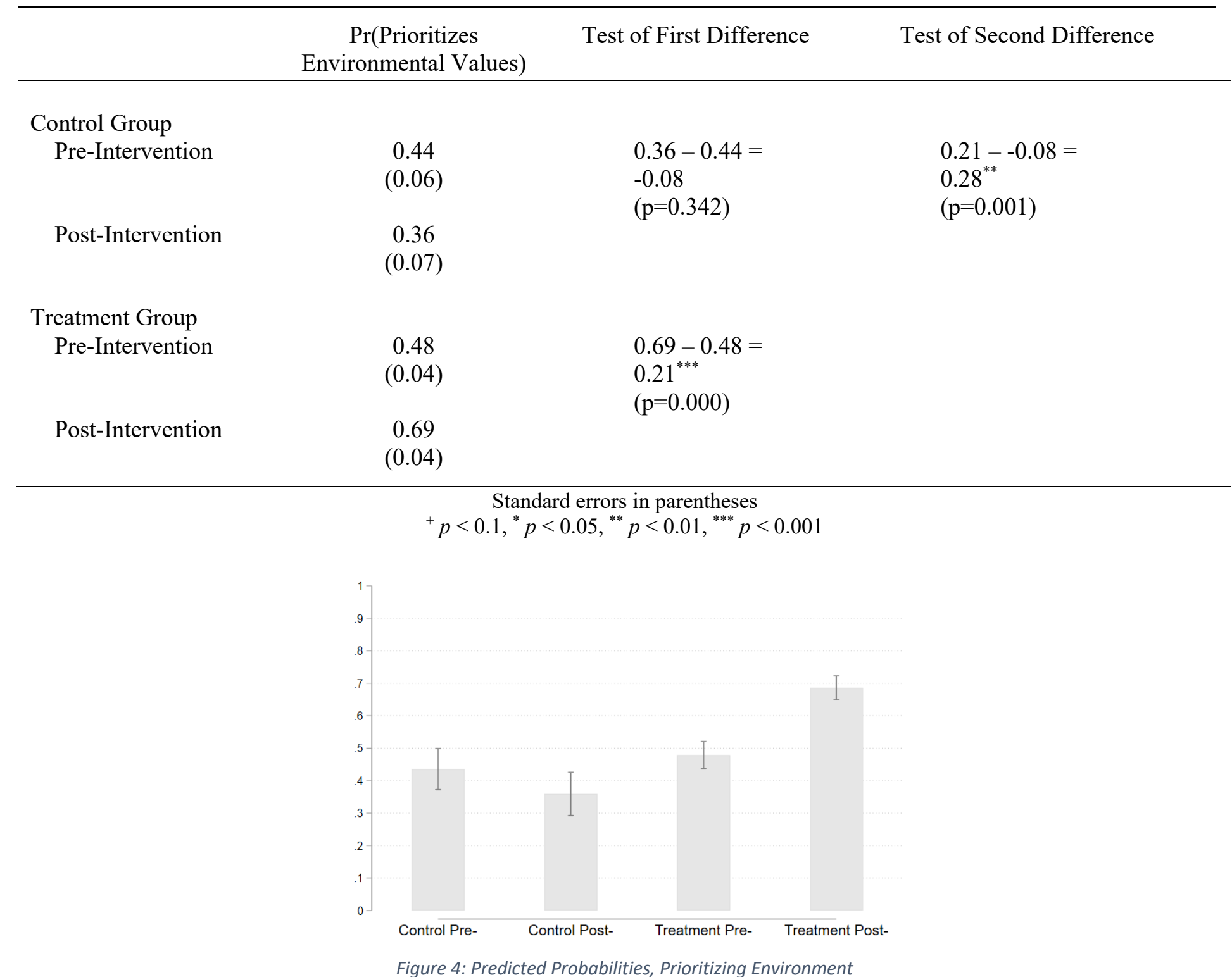

Figure 4: Predicted Probabilities, Prioritizing Environment 